NBER WORKING PAPER SERIES

\title{
RECIPROCAL TRADE LIBERALIZATION
}

Kyle Bagwell

Robert W. Staiger

Working Paper 5488

\section{NATIONAL BUREAU OF ECONOMIC RESEARCH \\ 1050 Massachusetts Avenue \\ Cambridge, MA 02138 \\ March 1996}

We thank Susan Athey, Jagdish Bhagwati, Alan Deardorff, Giovanni Maggi, Garey Ramey, Dani Rodrik and seminar participants at Chicago, Columbia, Dartmouth, Michigan, Northwestern, Stanford, UC Santa Cruz and Wisconsin for helpful discussion and comments. We are especially grateful to Gene Grossman for providing extensive comments on an earlier draft. This paper is part of NBER's research program in International Trade and Investment. Any opinions expressed are those of the authors and not those of the National Bureau of Economic Research.

(C) 1996 by Kyle Bagwell and Robert W. Staiger. All rights reserved. Short sections of text, not to exceed two paragraphs, may be quoted without explicit permission provided that full credit, including $\odot$ notice, is given to the source. 


\title{
RECIPROCAL TRADE LIBERALIZATION
}

\begin{abstract}
Why have governments found reciprocal trade agreements such as GATT to be a more effective means of facilitating trade liberalization than unilateral initiatives? We provide in this paper an analytic framework for the study of reciprocal trade agreements. We use this framework to establish three main results. First, we argue that political-economy factors are important for explaining the range of trade policies observed, but that these factors cannot explain why governments seek reciprocal trade agreements as an institutional form for implementing their preferred policies. Rather, whether or not governments are politically motivated, Johnson (195354) was right: The central purpose of a reciprocal trade agreement is to eliminate the terms-oftrade driven policies that arise in the absence of such an agreement. Second, we establish an economic interpretation of the principles of reciprocity and nondiscrimination that represent the foundation of postwar reciprocal trade agreements. Finally, we offer new insights regarding the treatment of export subsidies in reciprocal trade agreements.
\end{abstract}

Kyle Bagwell

Department of Economics

Northwestern University

2003 Sheridan Road

Evanston, IL 60208
Robert W. Staiger

Department of Economics

University of Wisconsin

1180 Observatory Drive

Madison, WI 53706 and NBER 


\section{Introduction}

The important role played by multilateral trade negotiations in shaping postwar trade policy is widely accepted. There is also broad consensus that the principles of reciprocity (the balance of concessions that governments seek to obtain through negotiation) and nondiscrimination (the requirement that each country adopt a uniform trade policy across trading partners) are the two main pillars of the multilateral institutions (GATT and the WTO) that were erected to facilitate these negotiations. Yet, at the same time, the motivations of governments that seek negotiations are poorly understood, and it is not clear why these pillars have served so successfully as the basis for postwar liberalization.

In thinking about multilateral trade negotiations, the most basic question is: Why have governments found reciprocal trade agreements such as GATT to be a more effective means of facilitating trade liberalization than unilateral initiatives? The challenge for economists in answering this question is that governments approach reciprocal trade liberalization from a strongly mercantilist perspective, a perspective that appears distinctly uneconomic. Indeed, the mercantilist orientation is rooted in the language of GATT itself, where the decision by a government to lower its import restrictions is viewed as a "concession" that is deemed worthy only for the export benefits that a reciprocal concession from a trading partner would generate. This perspective is difficult to reconcile with standard economic arguments, which hold that free trade is the best unilateral trade policy.

Given this state of affairs, a common view is that reciprocal trade agreements fall outside the purview of economics, being better explained as a product of "politics." Krugman (1991, pp.25-27) states this view most clearly:

There is no generally accepted label for the theoretical underpinnings of the GATT. I like to refer to it as 'GATT-think' -- a simple set of principles that is entirely consistent, explains most of what goes on in the negotiations, but makes no sense in terms of economics...The reason why GATT-think works is, instead, that it captures some basic realities of the political process.

The political view holds that governments have objectives that are distinct from national income maximization, that they may be constrained by the need to maintain electoral support for their trade policies, and that it is these political objectives and constraints that explain the important 
features of reciprocal trade agreements such as GATT. Examples of recent papers that stress the political dimensions of reciprocal trade agreements include Grossman and Helpman (1995a, 1995b) and Hillman and Moser (1995).

A second and competing view holds that reciprocal trade agreements in fact can be understood with economic principles. Drawing on the early work of Johnson (1953-54), it can be argued that governments with national income objectives enter into reciprocal trade agreements to escape from a terms-of-trade driven prisoners' dilemma.' The basic dilemma is easily explained: A large country can gain from the unilateral imposition of a restrictive trade policy (the optimal tariff), since the associated change in the world price carries some of the distortionary cost of that policy to trading partners; however, when trading partners are similarly motivated, the resulting reduction in trade volume lowers the national income of all countries.

The view that reciprocal trade agreements are best explained as a product of politics has undeniable appeal, especially in light of the manifest political constraints under which real governments operate. On the other hand, the terms-of-trade motivation, while logically unassailable, has important and well-known limitations: It ignores the political process altogether, and it offers the anomalous prediction that large countries are tempted to tax exports. As a result of these limitations, the terms-of-trade argument is often dismissed as providing a convenient but implausible interpretation of reciprocal trade agreements. ${ }^{2}$

Nevertheless, while these two viewpoints are well recognized, a formal accounting of the precise roles played by the political process and terms-of-trade considerations in building a coherent theory of GATT is still an open issue. Do governments enter into reciprocal trade agreements in response to political pressures, or is the incentive to enter into such agreements best understood as an attempt to counteract the trade restrictions that are a consequence of terms-

\footnotetext{
'Other proponents of this view include Scitovszky (1942), McMillan (1986, 1989) and Coneybeare (1987). Dixit (1987) and Bagwell and Staiger (1990) also explore the terms-of-trade argument.

${ }^{2}$ For example, in discussing why the principles of GATT do not make economic sense, Krugman ( 1991) states: Finally, standard theory generally argues that free trade is the best unilateral policy, regardless of whether other countries do the same. That is, in standard theory one does not need to justify free trade in the context of international agreements. (The qualification is the optimal tariff argument, which generally plays no part at all in real-world trade discussions.) (Krugman, 1991, p. 26).
}

Similar positions are advanced by, among others, Bhagwati (1988, p. 33, 1991, p. 51), Ethier (1988, pp. 194-195), Krueger (1990, pp. 69-70), Lindert (1986, p.298), and Rodrik (1994, p. 28). 
of-trade motivations? The first purpose of this paper is to provide a formal framework in which the merits of each position can be assessed. We accomplish this by developing models of trade and protection in which political and terms-of-trade motivations are simultaneously featured.

We begin with a two-country general-equilibrium model of trade that allows for a wide range of possible government motivations. The preferences of each government are represented as a general function of its local prices and world prices. These preferences may reflect national income considerations, but they may also include political concerns for local prices that are distinct from those implied by national income maximization. A more concrete interpretation of political motives is offered in our second model, which is a two-country partial-equilibrium model. Following Baldwin (1987), we represent political concerns here by allowing governments to weigh producer surplus more heavily than consumer surplus and tariff revenue in the government welfare function. As Grossman and Helpman (1994) have argued, this welfare function can be understood to reflect the lobbying activities of firms.

These models make possible a distinction between the political and terms-of-trade motivations for trade policy, and we find that the implications for reciprocal trade agreements of these two considerations are sharply delineated. Political concerns are important, in so far as they determine the trade-policy goals (i.e., the efficiency frontier) of governments. For example, politically-motivated governments may not view free trade as the goal of a reciprocal trade agreement. While political concerns can influence a government's goals, however, they play no role in explaining why reciprocal trade agreements (as opposed to unilateral policies) can help reach those goals. Rather, whether or not governments are politically motivated, Johnson (195354) got it right: The central purpose of a reciprocal trade agreement is to eliminate the terms-oftrade driven trade restrictions that arise in the absence of such an agreement. ${ }^{3}$

The intuition that underlies this conclusion may be developed as follows. Whatever trade policy goals a government seeks to achieve, whether maximizing national income or pursuing non-economic objectives, the terms-of-trade implications of trade policy intervention lead to greater restrictions on trade than is efficient. For example, when a government imposes an

\footnotetext{
${ }^{3}$ See also Johnson (1965). In this paper, Johnson sketches at an informal level the broader implications of the terms-of-trade logic for reciprocal trade agreements.
} 
import tariff, its terms of trade improve, and part of the cost of this distortionary policy is borne by exporting countries, whose producers sell at a lower price. Similarly, when the government stimulates its export sector with an export subsidy, its terms of trade deteriorate, and so consumers in importing countries receive some of the benefits of the subsidy. These terms-oftrade externalities imply that the government faces less than the full cost of protecting its import competing sectors and exaggerated costs of stimulating its export sectors. As a consequence, governments tend to oversupply policies directed toward import protection and undersupply policies directed toward export promotion relative to the efficient intervention levels given their objectives. A reciprocal trade agreement can therefore benefit each government, if it serves as a mechanism through which the associated terms-of-trade driven restrictions can be eliminated.

This explains why an efficient agreement will eliminate terms-of-trade considerations from trade policy choices. To see that there are no further trade policy changes that can yield additional Pareto gains for the negotiating governments, suppose that all terms-of-trade considerations have been eliminated. Then each government has set its trade policy to achieve its preferred local prices without concern for the terms-of-trade implications of its intervention. Now consider a small change in the level of a country's intervention. Such a change will have three effects: (i) It will induce a small change in the country's local prices; (ii) it will induce a small change in the terms of trade; and (iii) through movement in the terms of trade, it will induce a small change in the local prices of its trading partners. But effects (i) and (iii) can not offer Pareto gains to governments, given that they have already set their policies to achieve preferred local prices, while the terms-of-trade movement in (ii) represents a pure international transfer. Consequently, once terms-of-trade considerations have been eliminated from the trade policy choices of member governments, no further Pareto gains are possible.

If Johnson (1953-54) was right, and trade agreements are about nothing more than eliminating terms-of-trade considerations from trade policy choices, what then of the formal models of reciprocal trade agreements that focus on political economy? These papers appear to fall in one of two categories: Either escaping from a terms-of-trade driven prisoner's dilemma is the sole purpose of the trade agreement and political economy only affects the efficiency frontier (as in, for example, Grossman and Helpman, 1995a, and Hillman and Moser, 1995), or an assumption is made at the outset that governments are prevented from offering direct export 
subsidies, and reciprocal liberalization is then the only available means by which a government can help its export interests (as in, for example, Grossman and Helpman, 1995b). Papers in the former category are consistent with our findings here, although the essential role played by termsof-trade concerns in these papers appears to have gone unnoticed. ${ }^{4}$ Papers in the latter category typically refer to GATT's proscription against export subsidies to motivate the assumed absence of such a policy option, and can therefore account for the desirability of a reciprocal agreement on import policies only through the existence of an agreement on export policies. ${ }^{5}$ As such, these papers offer incomplete theories of reciprocal trade agreements, since they leave unanswered the question of why countries would agree to restrict export policies to begin with.

Our second purpose in writing this paper is to offer an economic interpretation of the principles of reciprocity and nondiscrimination on which postwar multilateral trade negotiations have been based. Reciprocity is readily interpreted in terms of the desire of governments to exchange reductions in trade restrictions, so that more efficient outcomes may be realized: Under reciprocity, the terms-of-trade implications of each country's own liberalization are neutralized, thereby removing an obstacle which prevented each country from unilaterally liberalizing in the first place. From this view, reciprocity facilitates the removal of inefficient trade restrictions that arise in the absence of a trade agreement as a consequence of terms-of-trade motivations.

Similarly, we provide an economic rationale for the nondiscrimination principle. Intuitively, any local price achieved through discriminatory tariffs can be achieved by a nondiscriminatory tariff that generates the same multilateral trade volume. ${ }^{6}$ Consequently, deviations from the principle of nondiscrimination in the absence of a trade agreement cannot be

\footnotetext{
${ }^{4}$ For example, Grossman and Helpman (1995a) consider trade negotiations between governments that have both political and terms-of-trade motivations. While they are primarily interested in determining the structure of protection, they do note that one role for an efficient trade agreement is to eliminate the terms-of-trade influences from trade policy choices. By contrast, whether or not governments are politically motivated, we establish under general conditions that the elimination of terms-of-trade motivations remains the only source of mutual benefits for negotiating governments.

${ }^{5}$ For example, the two small countries contemplating free trade negotiations in Grossman and Helpman (1995b) would have no reason to negotiate a free trade agreement if each government were allowed to subsidize exports.

${ }^{6}$ Strictly speaking, this intuition is only valid in a partial equilibrium setting where income effects are absent. More generally, the income effect in moving from discriminatory to nondiscriminatory tariffs might require changes in the multilateral trade volume to maintain constant local prices.
} 
explained as the result of a political preference for particular local prices, but instead must reflect the pursuit of beggar-thy-neighbor terms-of-trade effects. The principle of nondiscrimination thus also conforms with our general conclusion as to the purpose of a reciprocal trade agreement, as it promotes efficiency by eliminating terms-of-trade driven restrictions in trade.

A final purpose for this paper is to develop a framework with which to better understand the treatment of export subsidies in reciprocal trade agreements. As mentioned above, one limitation of the traditional terms-of-trade model is that it predicts that governments would impose export taxes in the absence of a trade agreement. Our model does not share this limitation: The observed practice of export subsidization can arise when governments interact non-cooperatively, provided that political concerns are pronounced. In this case, the traderestricting bias attributable to terms-of-trade concerns results in an export subsidy that is inefficiently small, and the role for a reciprocal trade agreement is to encourage further export subsidization. This observation, however, raises a new puzzle, since as noted above the official policy in GATT is that export subsidies are prohibited. ${ }^{7}$

In an extended model, we consider why governments might seek restrictions on export subsidies as part of a reciprocal trade agreement. Following the strategic-trade literature as pioneered by Brander and Spencer (1985), we assume that each of two countries exports to consumers in a third country. In contrast to Brander and Spencer, however, we assume that the export market is competitive. We find that important features of the strategic-trade argument continue to apply, provided that exporting governments are motivated by both terms-of-trade and political-economy concerns. In particular, while export subsidies remain inefficiently low, the exporting governments experience a Prisoner's Dilemma problem and would benefit from a reciprocal trade agreement that restrains export subsidies. Having demonstrated that these results are not limited to oligopolistic markets, we next argue that our model offers a useful framework with which to interpret discussions concerning export subsidies in agricultural markets.

The rest of the paper proceeds as follows. Section II presents our general-equilibrium model and develops our basic points regarding the purpose of a reciprocal trade agreement and

\footnotetext{
'In fact, as Jackson (1989) notes, the treatment of subsidies in GATT reflects some ambiguity as to their overall desirability. For example, R\&D subsidies are permitted, even when they may be similar in effect to export subsidies.
} 
the principle of reciprocity. Section III develops similar arguments in the context of our partialequilibrium model, in which political concerns are represented concretely. Section IV extends our results to a many country world, and provides an efficiency rationale for the principle of nondiscrimination. Section V considers an extended model in which some countries benefit from a restraint on export subsidies, and evaluates the consequences for world welfare when they are successful in doing so. Section VI concludes and discusses caveats associated with our findings.

\section{Reciprocal Trade Agreements in a Two-Country General-Equilibrium Framework}

We begin with a standard two-sector, two-country perfectly-competitive generalequilibrium trade model. Two countries, home (no *) and foreign (*), trade two goods, $\mathrm{x}$ and $y$, produced under conditions of increasing opportunity costs. Production takes place under perfect competition, facing tariffs on imports by each country. Let $x(y)$ be the natural import good of the home (foreign) country, and define $p \equiv p_{x} / p_{y}$ to be the local relative price facing home producers and consumers, with $p^{*} \equiv p_{x}^{*} / p_{y}^{*}$ the local relative price facing foreign producers and consumers. With $t\left(t^{*}\right)$ representing the home (foreign) ad valorem import tariff which we take to be non-prohibitive, and with $\tau \equiv(1+t)$ and $\tau^{*} \equiv\left(1+t^{*}\right)$, we have $p=\tau p^{w} \equiv p\left(\tau, p^{w}\right)$ and $p^{*}=p^{w} / \tau^{*} \equiv p^{*}\left(\tau^{*}, p^{w}\right)$, where $p^{w} \equiv p_{x}^{*} / p_{y}$ is the "world" (untaxed) relative price. The foreign (domestic) terms of trade are then measured by $\mathrm{p}^{\mathrm{w}}\left(1 / \mathrm{p}^{\mathrm{w}}\right)$. We interpret $\tau>1 \quad(\tau<1)$ to be an import tax (import subsidy), and similarly for $\tau^{*}{ }^{8}$

Production in each country is determined by selecting the point on its production possibilities frontier at which the marginal rate of transformation between $\mathrm{x}$ and $\mathrm{y}$ is equal to local relative prices: $Q_{i}=Q_{i}(p)$ and $Q_{i}^{*}=Q_{i}^{*}(p *)$ for $\mathrm{i}=\{\mathrm{x}, \mathrm{y}\}$. Consumption will be determined by local and world relative prices, with the latter entering the budget constraint through the lumpsum disposition of tariff revenue: $C_{i}=C_{i}\left(p, p^{w}\right)$ and $C_{i}^{*}=C_{i}^{*}\left(p^{*}, p^{w}\right)$ for $\mathrm{i}=\{\mathrm{x}, \mathrm{y}\}$. Homecountry imports of $\mathrm{x}, M_{x}\left(p\left(\tau, p^{w}\right), p^{w}\right)$, are then given by the difference between homecountry consumption and production of $\mathrm{x}$, while home-country exports of $\mathrm{y}, E_{y}\left(p\left(\tau, p^{w}\right), p^{w}\right)$,

\footnotetext{
${ }^{8}$ The Lerner symmetry theorem ensures that trade taxes or subsidies can be equivalently depicted as applying to exports or to imports in this two-sector general equilibrium setting.
} 
are given by the difference between home-country production and consumption of y. Foreign country imports of $\mathrm{y}, M_{y}^{*}\left(p^{*}\left(\tau^{*}, p^{w}\right), p^{w}\right)$, and exports of $\mathrm{x}, E_{x}^{*}\left(p^{*}\left(\tau^{*}, p^{w}\right), p^{w}\right)$, are similarly defined. For any world price we have balanced trade if budget constraints are satisfied:

$$
p^{w} M_{x}\left(p\left(\tau, p^{w}\right), p^{w}\right)=E_{y}\left(p\left(\tau, p^{w}\right), p^{w}\right)
$$

Finally, the equilibrium world price $\tilde{p}^{w}(\tau, \tau *)$ is determined by

$$
E_{y}\left(p\left(\tau, \tilde{p}^{m}\right), \tilde{p}^{w}\right)=M_{y}^{*}\left(p^{*}\left(\tau^{*}, \tilde{p}^{m}\right), \tilde{p}^{w}\right)
$$

We let the objectives of the home and foreign governments be represented by the functions $W\left(p\left(\tau, \tilde{p}^{w}\left(\tau, \tau^{*}\right)\right), \tilde{p}^{w}\left(\tau, \tau^{*}\right)\right)$ and $W^{*}\left(p^{*}\left(\tau^{*}, \tilde{p}^{w}\left(\tau, \tau^{*}\right)\right), \tilde{p}^{w}\left(\tau, \tau^{*}\right)\right)$, respectively. These objective functions could reflect national income goals, but they could also reflect government concern for local prices quite apart from the implications of these prices for national income. For example, we allow but do not insist that a government's concern about income distribution/political economy dictates its preferences over local prices. ${ }^{9}$

In any event, the primary structure we place on $\mathrm{W}$ and $\mathrm{W}^{*}$ is that, holding local prices fixed, each government is assumed to achieve higher welfare with a terms-of-trade improvement:

$$
\partial W\left(p, \tilde{p}^{w}\right) / \partial p^{w}<0 ; \quad \partial W^{*}\left(p^{*}, \tilde{p}^{w}\right) / \partial p^{w}>0
$$

With local prices held fixed, an improvement in a country's terms-of-trade amounts to a direct income transfer from its trading partner. We also assume that the second-order conditions associated with the maximization problems developed below are globally satisfied. ${ }^{10}$

${ }^{9}$ This representation of government preferences can also be modified to allow for the possibility that each government might face a binding political constraint in setting trade policy. For example, letting $G$ represent domestic government objectives, we can represent the domestic political constraint faced by the domestic government through the inequality restriction $V\left(p\left(\tau, \tilde{p}^{w}\left(\tau, \tau^{*}\right)\right), \tilde{p}^{w}\left(\tau, \tau^{*}\right)\right) \geq \bar{V}$. Forming the Lagrangian, $\mathrm{W}$, would then define the domestic government's constrained maximization problem, with $\rho$ the Lagrange multiplier:

$$
W\left(p\left(\tau, \tilde{p}^{\omega}\left(\tau, \tau^{*}\right)\right), \tilde{p}^{\omega}\left(\tau, \tau^{*}\right)\right) \equiv G\left(p\left(\tau, \tilde{p}^{\omega}\left(\tau, \tau^{*}\right)\right), \tilde{p}^{\omega}\left(\tau, \tau^{*}\right)\right)-\rho\left[V\left(p\left(\tau, \tilde{p}^{\omega}\left(\tau, \tau^{*}\right)\right), \tilde{p}^{\omega}\left(\tau, \tau^{*}\right)\right)-\bar{V}\right] .
$$

While $\rho$ is a choice variable, its optimal value will be a function of $p$ and $\tilde{D}^{w}$ as well.

${ }^{10}$ This amounts to regularity conditions on $\mathrm{W}$ and $\mathrm{W}$. In the next section, we confirm that these regularity conditions are satisfied for our partial-equilibrium model. 


\section{II.1 A Role for Reciprocal Trade Agreements}

We begin by supposing that each government sets its trade policy unilaterally, selecting a tariff to maximize its objective function taking the tariff choice of its trading partner as given. The home and foreign reaction functions, respectively, are defined implicitly by

$$
\text { Home: } W_{p}[d p / d \tau]+W_{p^{w}}\left[\partial \tilde{p}^{w} / \partial \tau\right]=0 ; \text { Foreign: } W_{p}^{*} \cdot\left[d p^{*} / d \tau^{*}\right]+W_{p}^{*}\left[\partial \tilde{p}^{w} / \partial \tau^{*}\right]=0
$$

where subscripts denote partial derivatives. Under standard conditions ruling out the Metzler and Lerner paradoxes, we have $d p / d \tau>0, d p^{*} / d \tau^{*}<0, \partial \tilde{p}^{w} / \partial \tau<0$ and $\partial \tilde{p}^{w} / \partial \tau^{*}>0$. Thus, with $\lambda \equiv\left[\partial \tilde{p}^{w} / \partial \tau\right] /[d p / d \tau]<0$ and $\lambda^{*} \equiv\left[\partial \tilde{p}^{w} / \partial \tau^{*}\right] /\left[d p^{*} / d \tau^{*}\right]<0$, (4) can be rewritten as

$$
\text { Home: } W_{p}+\lambda W_{p^{w}}=0 \text {, }
$$

$$
\text { Foreign: }-W_{p}^{*}-\lambda^{*} W_{p^{w}}^{*}=0 \text {. }
$$

Expressions (5a) and (5b) identify the two forces that combine to determine trade policy when governments set tariffs non-cooperatively in a Nash equilibrium: The impact of trade intervention on local prices and the impact of trade intervention on the terms of trade. The term $W_{p}$ in (5a) reflects the net benefit for the home government of providing slightly more favorable terms for import-competing interests in the home country (a slightly higher $p$ ) holding world prices fixed. The term $\lambda W_{p^{*}}$ in (5a), which by (3) is strictly positive, captures the amount by which the cost of a slightly higher $p$ is shifted on to the foreign country through the income effect of a change in the terms of trade ( a lower $p^{w}$ ). Likewise, the term $-W_{p}^{*}$. in (5b) reflects the net benefit for the foreign government of providing slightly more favorable terms for importcompeting interests in the foreign country (a slightly lower $\mathrm{p}^{*}$ ) holding world prices fixed, while the term $-\lambda^{*} W_{p}^{*}$ in (5b) is strictly positive by (3), and captures the amount by which the cost of a slightly lower $\mathrm{p}^{*}$ is shifted on to the domestic country through the income effect of a termsof-trade change (a higher $p^{w}$ ). Hence, as (5a) and (5b) indicate, the terms-of-trade effects of intervention ensure that neither government will face the full cost of serving its import-competing interests. Finally, Nash equilibrium tariffs are a pair of domestic and foreign tariffs $\left(\tau^{N}, \tau^{* N}\right)$ 
which simultaneously satisfy (5a) and (5b)."

We take the purpose of a reciprocal trade agreement as seeking tariff changes that result in Pareto improvements for member countries (as measured by $\mathrm{W}$ and $\mathrm{W}^{*}$ ) over what could be achieved through unilateral tariff setting. ${ }^{12}$ That is, we assume governments seek reciprocal trade agreements to achieve mutually beneficial changes in trade policy while respecting the sovereign right of each government to define its national goals. Reciprocal trade liberalization then refers to mutual reductions in tariffs implemented through a reciprocal trade agreement. An efficient reciprocal trade agreement will move governments to the efficiency locus, defined by

$$
\left.\left[d \tau / d \tau^{*}\right]\right|_{d W=0}=\left.\left[d \tau / d \tau^{*}\right]\right|_{d W^{*}=0}
$$

The inefficiency of the Nash equilibrium is now immediate, and we record it in:

Proposition 1: Nash equilibrium tariffs are inefficient.

Proof: We begin by noting that

$$
\left.\frac{d \tau}{d \tau^{*}}\right|_{d W=0}=-\frac{\partial \tilde{p}^{w} / \partial \tau^{*}}{d p / d \tau}\left[\frac{\tau W_{p}+W_{p^{w}}}{W_{p}+\lambda W_{p^{w}}}\right] ;\left.\quad \frac{d \tau}{d \tau^{*}}\right|_{d W^{*}=0}=-\frac{d p^{*} / d \tau^{*}}{\partial \tilde{p}^{w} / \partial \tau}\left[\frac{W_{p^{*}}^{*}+\lambda^{*} W_{p^{w}}^{*}}{W_{p}^{*} / \tau^{*}+W_{p^{w}}^{*}}\right]
$$

At a pair of Nash equilibrium tariffs $\left(\tau^{N}, \tau^{* N}\right),\left.\left[d \tau / d \tau^{*}\right]\right|_{d w=0}=\infty>0=\left.\left[d \tau / d \tau^{*}\right]\right|_{d w^{*}=0}$ by (5a), (5b), and (7). Thus, by (6), the tariff pair $\left(\tau^{N}, \tau^{* N}\right)$ is inefficient.

\footnotetext{
"We postpone for now the issues of existence and uniqueness of Nash equilibria, addressing these fully in the partial-equilibrium model of the following section. We focus throughout the current section on statements that will be true of any Nash equilibrium with positive trade that is not Pareto dominated by other Nash equilibria. An implication of this focus is that we ignore here and throughout the paper the possible gains from a reciprocal trade agreement that could come from coordinating across Pareto ranked Nash equilibria. The lack of enforcement issues associated with pure coordination gains and the prominence of enforcement issues in actual trade agreements suggests that pure coordination is not the primary objective of reciprocal trade agreements in practice. Similarly, we ignore for now the issue of existence and uniqueness of politically optimal and efficient tariffs, as defined below; these issues are also addressed fully in the partial-equilibrium model of the next section.

${ }^{12}$ Implicit in this statement is the assumption that governments find trade policy a more effective policy tool for achieving certain national goals than purely domestic policy tools, and that this is true independent of the terms-oftrade effects of intervention. It is also possible that by inducing governments to set policy without terms-of-trade effects in mind, a trade agreement could cause a change in the preferred instruments of intervention.
} 
Proposition 1 implies that Pareto improvements from the Nash equilibrium could be achieved through an appropriate reciprocal trade agreement. Figure 1 illustrates with $\tau$ on the vertical and $\tau^{*}$ on the horizontal axis. The Nash point marked $\mathrm{N}$ lies off the efficiency locus marked EE and corresponds to a point of vertical (horizontal) slope for the domestic (foreign) government iso-welfare contour. Next we characterize the nature of reciprocal trade agreements.

Proposition 2: Starting from a Nash equilibrium, any reciprocal trade agreement that is mutually beneficial must entail reciprocal trade liberalization.

Proof: We wish to establish that a necessary condition for a tariff pair $\left(\tau^{0}, \tau^{* 0}\right)$ to yield welfare improvements for both the domestic and foreign government relative to the Nash tariffs $\left(\tau^{\mathrm{N}}, \tau^{* \mathrm{~N}}\right)$ is that $\tau^{0}<\tau^{N}$ and $\tau^{* 0}<\tau^{* N}$. To establish this we suppose that $\tau^{0}>\tau^{N}$ and show that the foreign government must loose. The other case in which $\tau^{*}>\tau^{* \mathrm{~N}}$ can be handled in an analogous way.

First consider the impact of each country's tariff change on the welfare of its trading partner, given by $d W / d \tau^{*}=\left[\tau W_{p}+W_{p^{*}}\right]\left[\partial \tilde{p}^{w} / \partial \tau^{*}\right]$ and $d W^{*} / d \tau=\left[W_{p}^{*} \cdot / \tau^{*}+W_{p}^{*}\right]\left[\partial \tilde{p}^{w} / \partial \tau\right]$, respectively. Recalling that (5a) and (5b) define, respectively, the domestic and foreign reaction functions $\tau^{\mathrm{R}}\left(\tau^{*}\right)$ and $\tau^{* \mathrm{R}}(\tau)$, we note that when the domestic or foreign government, respectively, is on its reaction function, the impact on its welfare of a rise in its trading partner's tariff is

$$
d W / d \tau^{*}=\left[1-\tau^{R}\left(\tau^{*}\right) \lambda\right] W_{p^{w}}\left[\partial \tilde{p}^{w} / \partial \tau^{*}\right]<0 ; \quad d W^{*} / d \tau=\left[1-\lambda^{*} / \tau^{* R}(\tau)\right] W_{p^{*}}^{*}\left[\partial \tilde{p}^{w} / \partial \tau\right]<0 .
$$

These inequalities imply that, along each government's reaction function, its welfare is strictly declining in the tariff of its trading partner. With this we now have that $\tau^{0}>\tau^{\mathrm{N}}$ implies

$$
\begin{aligned}
& W^{*}\left(p^{*}\left(\tau^{* o}, \tilde{p}^{w}\left(\tau^{o}, \tau^{* \sigma}\right)\right), \tilde{p}^{w}\left(\tau^{o}, \tau^{* o}\right)\right) \leq W^{*}\left(p^{*}\left(\tau^{* R}\left(\tau^{o}\right), \tilde{p}^{w}\left(\tau^{o}, \tau^{* R}\left(\tau^{o}\right)\right)\right), \tilde{p}^{w}\left(\tau^{o}, \tau^{* R}\left(\tau^{o}\right)\right)\right) \\
& <W^{*}\left(p^{*}\left(\tau^{* R}\left(\tau^{N}\right), \tilde{p}^{w}\left(\tau^{N}, \tau^{* R}\left(\tau^{N}\right)\right)\right), \tilde{p}^{w}\left(\tau^{N}, \tau^{* R}\left(\tau^{N}\right)\right)\right)=W^{*}\left(p^{*}\left(\tau^{* N}, \tilde{p}^{w}\left(\tau^{N}, \tau^{* N}\right)\right), \tilde{p}^{w}\left(\tau^{N}, \tau^{* N}\right)\right) .
\end{aligned}
$$

Thus, the foreign government must be hurt by any change in tariffs that involves increasing the domestic tariff from its Nash level. Exactly analogous arguments establish that the domestic government must be hurt by any change in tariffs that involves increasing the foreign tariff from its Nash level. Hence, a necessary condition for tariff changes from the Nash equilibrium to improve a government's welfare is that its trading partner liberalize, and any reciprocal trade 
agreement that is mutually beneficial must entail reciprocal trade liberalization.

We have shown that the Nash equilibrium is inefficient (Proposition 1) and that a reciprocal trade agreement must lead to reciprocal trade liberalization (Proposition 2). In terms of Figure 1, reciprocal trade agreements must result in movements to the southwest of the Nash point. Reciprocal trade liberalization is therefore attractive to governments regardless of their political inclination, and indeed, whether governments act as national income maximizers or as agents for politically powerful interest groups.

We next show that a reciprocal trade agreement will be efficient if it eliminates the termsof-trade motivations from each government's Nash trade policy decisions and implements tariffs which jointly satisfy

$$
\text { Home: } \quad W_{p}=0 \text {, }
$$

$$
\text { Foreign: } \quad W_{p *}^{*}=0
$$

We define politically optimal tariffs as any tariff pair $\left(\tau^{P O}, \tau^{* P O}\right)$ satisfying $(8 \mathrm{a})$ and $(8 \mathrm{~b})$. The efficiency properties of politically optimal tariffs are now immediate:

Proposition 3: Politically optimal tariffs are efficient.

Proof: Using (7), we have $\left.\left[d \tau / d \tau^{*}\right]\right|_{d w=0}=-\left[\partial \tilde{p}^{w} / \partial \tau^{*}\right] /\left[\partial \tilde{p}^{w} / \partial \tau\right]=\left.\left[d \tau / d \tau^{*}\right]\right|_{d W^{*}=0}$ at politically optimal tariffs defined by (8a) and (8b) which by (6) are efficient.

QED

Figure 1 illustrates, by depicting the political optimum as a point on the efficiency locus. While Proposition 3 establishes the sufficiency of politically optimal tariffs for achieving an efficient trade agreement, a remaining question concerns the necessity of politically optimal tariffs for efficiency. To address this question, we first define: 


$$
A \equiv \frac{(1-\tau \lambda)}{\left(W_{p}+\lambda W_{p}\right)} ; \quad A^{*} \equiv \frac{\left(1-\lambda^{*} / \tau^{*}\right)}{\left(W_{p^{*}}^{*}+\lambda^{*} W_{p^{\omega}}^{*}\right)}
$$

where $A \neq 0$ and $A^{*} \neq 0$ under the further assumption that the partial derivatives for the welfare functions are always finite. We may now use (6) and (7) to derive that the efficiency locus is characterized by:

$$
\left(1-A W_{p}\right)\left(1-A^{*} W_{p}^{*}\right)=1
$$

Consider now the case in which countries are symmetric (i.e., $W \equiv W^{*}, \lambda=\lambda^{*}$ at $\tau=\tau^{*}$ ) and adopt symmetric tariffs (i.e., $\tau=\tau^{*}$ ). In this event, the efficiency-locus condition reduces to $\left(1-A W_{p}\right)^{2}=1$. Given that $A \neq 0$, this condition can hold only if $W_{p}=0$, which establishes that:

Proposition 4: The efficient symmetric reciprocal trade agreement between symmetric countries must implement the politically optimal tariffs.

In the symmetric case, therefore, politically optimal tariffs are necessary for efficiency.

For asymmetric environments, efficiency need not imply that tariffs are politically optimal. This can be seen by noting that the efficiency condition given above can be satisfied even if $W_{p} \neq 0$ and $W_{p}^{*} \neq 0$. The reason that there can exist efficient agreements that do not implement politically optimal tariffs is that it may not be possible to fully compensate a country for the adverse terms-of-trade movements that come with liberalization to its politically optimal tariffs. Thus, the inability to make international lump sum transfers introduces the possibility of efficient agreements that do not implement politically optimal tariffs. ${ }^{13}$

It is interesting to note that the needed lump sum international transfers can not in general be accomplished by altering the terms of trade through adjustments in $\tau$ and $\tau^{*}$, since any local relative price changes engendered by such adjustments would be a concern to politically

\footnotetext{
${ }^{13}$ For instance, it is easy to construct examples in which an efficient agreement exists which does not implement politically optimal tariffs in a two-country two-good endowment economy where all individuals have identical and homothetic preferences and governments care about local prices for distributional as well as efficiency reasons.
} 
motivated governments. ${ }^{14}$ This stands in contrast to the case in which governments maximize national income (see Mayer, 1981) and therefore require for efficiency only that local relative prices are equal across countries, a condition that can be achieved with many combinations of $\tau$ and $\tau^{*}{ }^{15}$ This is also in contrast to the partial-equilibrium model of the next section, where politically motivated governments have sufficient tariff instruments to alter world prices without changing local prices in either country.

Since the distinction between Nash and politically optimal tariffs is that in the former the terms-of-trade effects of trade policy intervention are allowed to influence each government's trade policy choices, Propositions 1 through 4 identify the central role played by terms-of-trade effects in setting the foundation for reciprocal trade liberalization. As indicated above and depicted in Figure 1, the terms-of-trade effects of protection lead to a systematic understatement of the full costs of adopting trade policies that favor import-competing sectors and impart an antitrade bias to unilateral trade policy decisions. It is then the purpose of a reciprocal trade agreement to induce each country to internalize the full costs of its national policy goals, an act which reverses the anti-trade bias of unilateral decisions and brings about reciprocal trade liberalization. ${ }^{16}$ Thus, whether or not governments are politically motivated, the essence of $a$ reciprocal trade agreement is to eliminate terms-of-trade considerations from trade policy

\footnotetext{
${ }^{14}$ It might seem that the introduction of an explicit international transfer mechanism would then insure that all efficient trade agreements implement politically optimal tariffs (Indeed, an earlier draft included a claim to this effect; we thank Gene Grossman for bringing this error to our attention). However, an explicit transfer mechanism can not offer anything that an adjustment in tariffs alone could not achieve. Lump sum international transfers are therefore in general simply not possible if governments care about local prices for reasons other than efficiency.

${ }^{15}$ Mayer (1981) also considers briefly how the locus of efficient trade agreements changes with the introduction of political interest groups into one country. There, as here, changes in tariffs can no longer orchestrate lump-sum international transfers.

${ }^{16}$ This view of the purpose of reciprocal trade agreements is noted by Jackson (1989) in his discussion of possible exceptions to the claim that reciprocal free trade is the only legitimate goal of a trade agreement: More subtle is the possibility that a national consensus could explicitly opt for a choice of policies that would not maximize wealth (in the traditionally measurable sense, at least), but would give preference to other noneconomic goals. For example, the choice might be to preserve an agricultural way of life for groups of citizens used to it...There is little in international trade theory which can refute the validity of such choices on the part of nations, with perhaps one exception. It can be argued that when a nation makes an 'uneconomic' choice, it should be prepared to pay the whole cost, and not pursue policies which have the effect of unloading some of the burdens of that choice onto other nations. (Jackson, 1989, p. 19).
} 
choices. ${ }^{17}$

\section{II.2 Reciprocity}

We conclude this section with a final observation on the nature of reciprocal trade liberalization. As we noted in the Introduction, it is widely held that enthusiasm for reciprocal trade agreements is in practice rooted in a mercantilist perspective. For example, Krugman (1991, p. 25) observes:

To make sense of international trade negotiations, one needs to remember three simple rules about the objectives of the negotiating countries:

1) Exports are good.

2) Imports are bad.

3) Other things equal, an equal increase in imports and exports is good. In other words, GATT-think is enlightened mercantilism.

The question we now address is, can the mercantilist approach to reciprocal trade liberalization that seems to drive actual negotiations be explained within our framework ${ }^{18}$

Our starting point is the observation that $\lambda W_{p}>0$ and $\lambda^{*} W_{p}{ }^{*}{ }<0$ : Hence, at any pair of Nash equilibrium tariffs satisfying (5a) and (5b), we must have $W_{p}<0, W_{p}^{*}>0$. These inequalities imply that each government sets its Nash tariff where, neutralizing the terms-of-trade effects of a change in trade policy intervention, a slightly less-restrictive trade policy would be strictly beneficial. Consider, then, combinations of $\tau$ and $\tau^{*}$ that lay along an iso-terms-of-trade locus. Provided that these loci are positively sloped, so that movements along an iso-terms-of-trade

\footnotetext{
${ }^{17}$ We focus on terms-of-trade effects as the critical transmission mechanism for international externalities associated with intervention, but other possibilities exist. For example, expenditure switching effects of import protection can impose externalities that are not associated with terms-of-trade movements when domestic distortions such as imperfect competition (Flam and Helpman, 1987, Helpman and Krugman, 1989) or Keynesian price rigidities (Robinson, 1947) are present. However, in this case an appropriate choice of a non-trade instrument to correct the domestic distortion would offer a unilateral mechanism for achieving greater government welfare than could be delivered by the policy of import protection alone. In the conclusion, we discuss the role that trade agreements might play when countries face constraints on the instruments available for addressing domestic distortions. On a related point, see also Chari and Kehoe (1990).

${ }^{18} \mathrm{An}$ additional benefit of reciprocity may be that the prospect of foreign concessions can be used to mobilize export support for one's own liberalization (see, for example, Bhagwati, 1991, p. 51). Our government objectives are consistent with this possibility (see note 9), and yet we find no support for the notion that governments seek reciprocity for this purpose. As such, it appears that the formal basis for this explanation is still an open issue.
} 
locus entail reciprocal tariff changes of a common sign, we have: ${ }^{19}$

Proposition 5: Beginning at a Nash tariff equilibrium, reciprocal trade liberalization that leaves the terms of trade unchanged will increase each government's welfare monotonically until this liberalization has proceeded to the point where $\min \left[-W_{p}, W_{p}^{*}.\right]=0$. If countries are symmetric, this liberalization path leads to the efficient symmetric reciprocal trade agreement.

Proof: Consider reciprocal reductions in $\tau$ and $\tau^{*}$ beginning from the Nash equilibrium and moving along the positively-sloped iso-terms-of-trade locus that passes through $\left(\tau^{\mathrm{N}}, \tau^{* \mathrm{~N}}\right)$. With $\mathrm{dp}^{\mathrm{w}}=0$, the impact of a small amount of reciprocal liberalization along this path on domestic government welfare $\mathrm{W}$ is just $-W_{p}(\partial p / \partial \tau) d \tau$ while the impact on foreign government welfare $\mathrm{W}^{*}$ is $-W_{p^{*}}^{*}\left(\partial p^{*} / \partial \tau^{*}\right) d \tau^{*}$. Both are strictly positive around the Nash equilibrium, and both continue to be strictly positive until liberalization has proceeded down this path to the point where $\min \left[-W_{p}, W_{p}^{*}.\right]=0$. If countries are symmetric, then both $W_{p}$ and $W_{p^{*}}^{*}$ will reach zero at the same point on the iso-terms-of-trade locus through $\left(\tau^{\mathrm{N}}, \tau^{* \mathrm{~N}}\right)$, defining a pair of politically optimal tariffs by (8a) and (8b).

QED

Together, Propositions 1 through 5 provide a formal economic interpretation of the apparent "mercantilist" behavior that seems to characterize actual trade negotiations, and of the emphasis on a "balance of concessions" that characterizes the reciprocity principle of GATT. First, they provide a reason why governments should view negotiations as a vehicle for expanding exports at the cost of expanded imports: Starting from a Nash equilibrium, it would be costly for a government to liberalize its import sectors unilaterally, but the efficiency gains from greater exports that come with reciprocal liberalization abroad make the concession of import liberalization at home worthwhile. Hence, negotiators have every reason to enter negotiations with the view that "exports are good and imports are bad." Moreover, a rationale for Krugman's third rule can be given as well: The iso-terms-of-trade locus that characterizes the

\footnotetext{
${ }^{19} \mathrm{~A}$ positively-sloped iso-terms-of-trade locus is guaranteed if substitution effects dominate income effects so that $M_{y}^{*}$ increases in $\mathrm{p}^{*}$ and $\mathrm{E}_{\mathrm{y}}$ decreases in $\mathbf{p}$.
} 
liberalization path of Proposition 5 describes reductions in $\tau$ and $\tau^{*}$ that lead to equal increases in the volume of imports and exports at existing world prices. This follows directly from the condition that trade is balanced at world prices and the fact that world prices are held fixed along this liberalization path. Thus, by entering into reciprocal trade negotiations, each government can gain if it offers concessions of import liberalization in exchange for reciprocally "balanced" concessions abroad which lead to equal increases in exports and imports. If countries are symmetric, then this liberalization path will lead to the efficient symmetric reciprocal trade agreement in which governments implement their politically optimal tariffs. ${ }^{20}$

\section{Reciprocal Trade Agreements in a Two-Country Partial-Equilibrium Framework}

With the general dimensions of our argument now established, we turn next to the development of a simple partial-equilibrium model. This model is useful for three main reasons. First, the model identifies political-economy influences in terms of specific parameters, and thus offers a concrete interpretation of the consequences of political economy for reciprocal trade agreements. Second, the partial-equilibrium model draws a distinction between import and export policies, permitting the development of new insights regarding export policies. Finally, the partial-equilibrium model also serves as a framework for further analysis, in which we consider motivations for the principle of nondiscrimination and restraints on export subsidies.

\section{III.1 Model}

As before, we consider a world economy in which two countries -- home (no ${ }^{*}$ ) and foreign $\left(^{*}\right)$-- trade two goods $x$ and $y$, with $x(y)$ the natural import good of the home (foreign) country. Our purpose in this subsection is to construct a simple linear model of the world economy, derive the associated market-clearing values for prices and quantities, and then express government objectives in terms of these values.

\footnotetext{
${ }^{20}$ While our results provide a formal rationale for the general principle of reciprocity found in GATT, the primary measure of the value of a concession that is often used by governments to calculate balances -- the percentage tariff cut multiplied by the volume of imports affected (see, for example, Jackson, 1989, pp. 123-124) -- must be interpreted within our framework as a rule-of-thumb for achieving reciprocity, since it bears no necessary relation to movements along the iso-terms-of-trade locus (see McMillan, 1989, for an alternative interpretation of this measure). Preeg (1970, p. 130) describes many additional factors used to assess reciprocity in the Kennedy Round.
} 
Basic Assumptions: Our specific assumptions on demand and production are as follows. With regard to demand, we assume that each good is demanded in each country according to a common linear demand function. Letting $\mathrm{p}_{\mathrm{x}}$ and $\mathrm{p}_{\mathrm{y}}$ denote the local prices of good $\mathrm{x}$ and $\mathrm{y}$ in the domestic market, the domestic demand function for good $i=\{x, y\}$ is given by $D\left(p_{i}\right)=1-p_{i}$. Foreign demand functions are symmetrically defined in terms of the foreign prices $p_{x}^{*}$ and $p_{y}^{*}$.

Supply functions also take a linear form. Each good is produced in a competitive market in each country, and the domestic (foreign) country has a comparative advantage in the production of good $\mathrm{y}(\mathrm{x})$. Specifically, we assume that domestic supply functions are given as $Q_{x}\left(p_{x}\right)=p_{x} / 2$ and $Q_{y}\left(p_{y}\right)=p_{y}$, while the foreign supply functions are given as $Q_{y}^{*}\left(p_{y}^{*}\right)=p_{y}^{*} / 2$ and $Q_{x}^{*}\left(p_{x}^{*}\right)=p_{x}^{*}$. The associated competitive profit functions are given by $\Pi_{x}\left(p_{x}\right)=\left(p_{x}\right)^{2} / 4, \Pi_{y}\left(p_{y}\right)=\left(p_{y}\right)^{2} / 2, \Pi_{y}^{*}\left(p_{y}^{*}\right)=\left(p_{y}^{*}\right)^{2} / 4$, and $\Pi_{x}^{*}\left(p_{x}^{*}\right)=\left(p_{x}^{*}\right)^{2} / 2 .^{21}$

Price Determination: With the demand, supply and profit functions presented, we turn next to price determination. To this end, let $\tau_{x}$ denote the (specific) import tariff applied by the domestic country to imports of good $x$, and let $\tau_{y}$ represent the (specific) export subsidy given by the domestic country to exports of good $y$. Similarly, we represent the foreign country's import tariff as $\tau_{y}^{*}$ and export subsidy as $\tau_{x}^{*} .22$

Provided trade taxes do not prohibit all trade, local prices in each country obey two conditions. First, local prices in each country must satisfy the arbitrage conditions: $p_{i}=p_{i}^{*}+\tau_{i}-\tau_{i}^{*}, i=x, y$. A second requirement is that local prices are set so that markets clear: $Q_{i}\left(p_{i}\right)+Q_{i}^{*}\left(p_{i}^{*}\right)=D\left(p_{i}\right)+D\left(p_{i}^{*}\right), i=x, y$. Solving these two sets of equations yields the market-clearing domestic prices, $p_{x}\left(\tau_{x}-\tau_{x}^{*}\right)$ and $p_{y}\left(\tau_{y}^{*}-\tau_{y}\right)$, as well as the associated foreign prices, $p_{x}^{*}\left(\tau_{x}-\tau_{x}^{*}\right)$ and $p_{y}^{*}\left(\tau_{y}^{*}-\tau_{y}\right)$. Observe that the market-clearing local prices depend upon

\footnotetext{
${ }^{21}$ The domestic supply and profit functions may be derived from underlying production functions of the form $Q_{x}=\left(L_{x}\right)^{1 / 2}$ and $Q_{y}=\left(2 L_{y}\right)^{1 / 2}$, where $L_{x}\left(L_{y}\right)$ is the labor used in the production of good $\mathrm{x}(\mathrm{y})$, under the assumption that labor supply is infinitely elastic at a unitary wage. Similar remarks apply for the foreign functions.

${ }^{22} \mathrm{~A}$ negative import tariff corresponds to an import subsidy, while a negative export subsidy is interpreted as an export tax.
} 
trade policy only through the corresponding net tariffs, $\tau_{x}-\tau_{x}^{*}$ and $\tau_{y}^{*}-\tau_{y}$. Given that demand (supply) functions are downward (upward) sloping, it is direct to confirm that a higher net tariff raises the local price in the importing country and lowers the local price in the exporting country.

Consider next the world (i.e., offshore) prices. Letting $p_{x}^{w}$ and $p_{y}^{w}$ denote the world price of goods $x$ and $y$, respectively, we have the following definition: $p_{i} \equiv p_{i}{ }^{\omega}+\tau_{i}, i=x, y$. Having already solved for the market-clearing local prices, we may thus represent the marketclearing world prices as $p_{x}^{w}\left(\tau_{x}, \tau_{x}^{*}\right)$ and $p_{y}^{w}\left(\tau_{y}, \tau_{y}^{*}\right)$. Using the monotonicity of the demand and supply functions, it is direct to confirm that the world price is decreasing in each argument: The world price falls when the import tariff is raised and when the export subsidy is increased. In contrast to local prices, the world price is not uniquely determined by the net tariff..$^{23}$ Exploiting the linear nature of the model, it is possible to express market-clearing world prices as $p_{x}{ }^{w}\left(\tau_{x}, \tau_{x}^{*}\right)=\left[4-4 \tau_{x}^{*}-3 \tau_{x}\right] / 7$ and $p_{y}{ }^{w}\left(\tau_{y}, \tau_{y}^{*}\right)=\left[4-4 \tau_{y}-3 \tau_{y}^{*}\right] / 7$. Finally, market-clearing local prices may also be expressed as explicit functions of world prices: $\hat{p}_{i}\left(\tau_{i}, p_{i}^{\omega}\left(\tau_{i}, \tau_{i}^{*}\right)\right)=p_{i}^{\omega}\left(\tau_{i}, \tau_{i}^{*}\right)+\tau_{i}$ and $\hat{p}_{i}^{*}\left(\tau_{i}^{*}, p_{i}^{\omega}\left(\tau_{i}, \tau_{i}^{*}\right)\right)=p_{i}^{\omega}\left(\tau_{i}, \tau_{i}^{*}\right)+\tau_{i}^{*}$.

Trade Volumes: We consider next the market-clearing import and export volumes. The domestic import volume for good $\mathrm{x}$ is denoted by $M\left(\hat{p}_{x}\right) \equiv D\left(\hat{P}_{x}\right)-Q_{x}\left(\hat{p}_{x}\right)=1-3 \hat{p}_{x} / 2$, and the domestic export volume of good y is represented by $E\left(\hat{p}_{y}\right) \equiv Q_{y}\left(\hat{p}_{y}\right)-D\left(\hat{p}_{y}\right)=2 \hat{p}_{y}-1$. It is now straightforward to derive conditions under which the trade volume is positive:

$$
M\left(\hat{p}_{x}\right)>0 \quad \text { iff } \quad \tau_{x}-\tau_{x}^{*}<1 / 6 ; \quad E\left(\hat{p}_{y}\right)>0 \quad \text { iff } \quad \tau_{y}^{*}-\tau_{y}<1 / 6 .
$$

Thus, trade occurs so long as the net tariff is not too large. Foreign import and export volumes, $M^{*}\left(\hat{p}_{y}^{*}\right)$ and $E^{*}\left(\hat{p}_{x}^{*}\right)$, are defined symmetrically, with $M^{*}\left(\hat{p}_{y}^{*}\right)=E\left(\hat{p}_{y}\right)$ and $M\left(\hat{p}_{x}\right)=E^{*}\left(\hat{p}_{x}^{*}\right)$ then following directly from the market-clearing requirement.

Government Objectives: We are now prepared to define government welfare functions. Governments are assumed to maximize a weighted sum of consumer surplus, producer surplus

\footnotetext{
${ }^{23}$ For example, if the import tariff and the export subsidy applied to a good are increased by one unit, so that the net tariff and thus the local prices are kept constant, then the world price of the good drops by one unit.
} 
and tariff revenue. Following Baldwin (1987), we allow for political-economy influences with the assumption that governments may weight producer surplus differently than consumer surplus and tariff revenue. This representation has recently been given micro-analytic foundations in the explicit lobbying model developed by Grossman and Helpman (1994). ${ }^{24}$

Let $\gamma_{m} \geq 1 \quad\left(\gamma_{e} \geq 1\right)$ denote the weight that the government attaches to the producer surplus earned by import-competing (exporting) firms. The welfare functions that the domestic government realizes on its import and export goods are then defined as follows:

$$
\begin{aligned}
& W_{x}\left(\hat{p}_{x}, p_{x}^{w}\right) \equiv \int_{\hat{p}_{x}}^{1} D\left(p_{x}\right) d p_{x}+\gamma_{m} \Pi_{x}\left(\hat{p}_{x}\right)+\left[\hat{p}_{x}-p_{x}^{w}\right] M\left(\hat{p}_{x}\right) \\
& W_{y}\left(\hat{p}_{y}, p_{y}^{w}\right) \equiv \int_{\hat{p}_{y}}^{1} D\left(p_{y}\right) d p_{y}+\gamma_{e} \Pi_{y}\left(\hat{p}_{y}\right)-\left[\hat{p}_{y}-p_{y}^{w}\right] E\left(\hat{p}_{y}\right) .
\end{aligned}
$$

The domestic-government welfare function is then the sum of the welfare achieved on the import good and the export good: $W\left(\hat{p}_{x}, \hat{p}_{y}, p_{x}{ }^{w}, p_{y}{ }^{w}\right) \equiv W_{x}\left(\hat{p}_{x}, p_{x}{ }^{w}\right)+W_{y}\left(\hat{p}_{y}, p_{y}{ }^{w}\right)$. The foreigngovernment import and export welfare functions take analogous forms:

$$
\begin{aligned}
& W_{y}^{*}\left(\hat{p}_{y x}^{*} p_{y}^{w}\right) \equiv \int_{\hat{p}_{y}^{*}}^{1} D\left(p_{y}^{*}\right) d p_{y}^{*}+\gamma_{m} \Pi_{y}^{*}\left(\hat{p}_{y}^{*}\right)+\left[\hat{p}_{y}^{*}-p_{y}^{w}\right] M^{*}\left(\hat{p}_{y}^{*}\right) \\
& W_{x}^{*}\left(\hat{p}_{x}^{*} p_{x}^{w}\right) \equiv \int_{\hat{p}_{x}^{*}}^{1} D\left(p_{x}^{*}\right) d p_{x}^{*}+\gamma_{e} \Pi_{x}^{*}\left(\hat{p}_{x}^{*}\right)-\left[\hat{p}_{x}^{*}-p_{x}^{w}\right] E^{*}\left(\hat{p}_{x}^{*}\right)
\end{aligned}
$$

so that $W^{*}\left(\hat{p}_{x}^{*}, \hat{p}_{y}^{*}, p_{x}^{w}, p_{y}^{w}\right) \equiv W_{y}^{*}\left(\hat{p}_{y}^{*}, p_{y}^{w}\right)+W_{x}^{*}\left(\hat{p}_{x}^{*}, p_{x}^{w}\right)$ defines the foreign welfare function.

\section{III.2 Nash Equilibria}

In this subsection, we consider a static tariff game, in which the domestic government

\footnotetext{
${ }^{24}$ In the lobbying model of Grossman and Helpman (1994), governments behave as if they place greater weight on the producer surplus of politically represented sectors provided that these sectors compose a small fraction of the overall economy.
} 
selects its tariff policy, $\left(\tau_{x}, \tau_{y}\right)$, in order to maximize its welfare, $W$, at the same time that the foreign government chooses its tariff policy, $\left(\tau_{y}^{*}, \tau_{x}^{*}\right)$, in order to maximize its welfare, $\mathrm{W}^{*}$. Our purpose is to characterize the set of Nash tariff policies, paying particular attention to the relation between Nash policies and the political-economy parameters, $\gamma_{m}$ and $\gamma_{e}$.

Before characterizing the Nash equilibria of the tariff game, it is instructive to recall from section II that the Nash tariffs will be determined by two forces: the impact of tariffs on world prices (the terms of trade) and the impact of tariffs on local prices. As before, it is through the terms-of-trade effect associated with world price movements that a country can redistribute surplus from its trading partner to itself. In our partial-equilibrium model, however, we can disentangle the local price effects into a political-economy effect and an efficiency effect. The political-economy effect refers to the ability of trade policy to redistribute surplus between domestic producers and domestic consumers or tariff revenue, holding the volume of trade fixed. Trade policies also have an efficiency effect through their impact on local prices, as these local price changes alter the volume of trade and thereby affect welfare. As with the generalequilibrium model of the previous section, we argue that the terms-of-trade effect leads governments to restrict trade more than if each were motivated only by local price considerations.

To develop this argument formally, we maximize $W$ with respect to $\tau_{x}$ and $\tau_{y}$ and maximize $W^{*}$ with respect to $\tau_{y}^{*}$ and $\tau_{x}^{*}$. Defining

$$
\begin{aligned}
& \lambda_{x} \equiv\left[\partial p_{x}{ }^{w} / \partial \tau_{x}\right] /\left[d \hat{p}_{x} / d \tau_{x}\right]=-3 / 4=\left[\partial p_{y}{ }^{w} / \partial \tau_{y}^{*}\right] /\left[d \hat{p}_{y}^{*} / d \tau_{y}^{*}\right] \equiv \lambda_{y}^{*} \\
& \lambda_{y} \equiv\left[\partial p_{y}^{w} / \partial \tau_{y} y\left[d \hat{p}_{y} / d \tau_{y}\right]=-4 / 3=\left[\partial p_{x}{ }^{w} / \partial \tau_{x}^{*}\right] /\left[d \hat{p}_{x}^{*} / d \tau_{x}^{*}\right] \equiv \lambda_{x}^{*},\right.
\end{aligned}
$$

the best-response tariffs for the domestic and foreign governments are defined implicitly by

$$
\text { Home: } W_{\hat{p}_{x}}+\lambda_{x} W_{p_{x}{ }^{w}}=0 ; W_{\hat{p}_{y}}+\lambda_{y} W_{p_{y}{ }^{w}}=0 \text { Foreign: } W_{\hat{p}_{y}^{*}}^{*}+\lambda_{y}^{*} W_{p_{y}^{w}}^{*}=0 ; W_{\hat{p}_{x}^{*}}^{*}+\lambda_{x}^{*} W_{p_{x}{ }^{w}}^{*}=0
$$

While expression (10) presents the first order conditions in analogous form to (5a) and (5b), the structure of the partial-equilibrium model developed in this section permits (10) to be written in a form more amenable to interpretation. For the domestic government, we have: 


$$
\begin{aligned}
& \left\{Q_{x}\left(\hat{p}_{x}\right)\left[\gamma_{m}-1\right]+\tau_{x}\left[\partial M / \partial \hat{p}_{x}\right]\right\}+\left[3 M\left(\hat{p}_{x}\right) / 4\right]=0 \\
& \left\{Q_{y}\left(\hat{p}_{y}\right)\left[\gamma_{e}-1\right]-\tau_{y}\left[\partial E / \partial \hat{p}_{y}\right]\right\}+\left[-4 E\left(\hat{p}_{y}\right) / 3\right]=0 .
\end{aligned}
$$

Exactly analogous conditions hold for the foreign government.

Consider now the import-policy condition (11a). The terms in curly brackets on the LHS of (11a) correspond to $W_{\hat{B}_{x}}$ in (10) and represent the local-price effects of a small increase in the domestic import tariff $\tau_{x}$. The first term inside the curly brackets, $Q_{x}\left(\hat{p}_{x}\right)\left[\gamma_{m}-1\right]$, measures the net effect on consumer surplus and import-competing producer surplus when the fixed $Q_{x}\left(\hat{p}_{x}\right)$ units of domestically produced and consumed $\mathrm{x}$ are exchanged domestically at a higher price. ${ }^{25}$ This political-economy effect is positive when the implied redistribution is desirable (i.e., when $\gamma_{m}>1$ ). The second term inside the curly brackets, $\tau_{x} \partial M / \partial \hat{p}_{x}$ is negative and captures the efficiency effect. It gives the efficiency cost to the domestic country when its import tariff is raised slightly, thereby inducing import volume (and tariff revenue) to fall. Finally, the last term on the LHS of $(11 a),(3 / 4) M\left(\hat{p}_{x}\right)$, is positive and corresponds to $\lambda_{x} W_{p_{x}{ }^{\prime \prime}}$ in (10). It represents the increase in tariff revenue collected on the $M\left(\hat{p}_{x}\right)$ units of imported $\mathrm{x}$ attributable to the reduction in the world price that follows a slight increase in the import tariff; this is the terms-of-trade effect, and it reflects a redistribution of surplus from foreign exporters to the domestic country. Condition (11b) admits a similar interpretation.

Letting $\tau_{x}^{R}\left(\tau_{x}^{*}\right)$ and $\tau_{y}^{R}\left(\tau_{y}^{*}\right)$ denote the domestic-government's import-tariff and exportsubsidy reaction curves, respectively, we next solve (11a) and (11b) to find that

$$
\tau_{x}^{R}\left(\tau_{x}^{*}\right)=\frac{\left[8 \gamma_{m}-5\right]+2 \tau_{x}^{*}\left[13-4 \gamma_{m}\right]}{4\left[17-2 \gamma_{m}\right]} ; \quad \tau_{y}^{R}\left(\tau_{y}^{*}\right)=\frac{4\left[3 \gamma_{e}-4\right]+3 \tau_{y}^{*}\left[11-3 \gamma_{e}\right]}{3\left[25-3 \gamma_{e}\right]}
$$

The corresponding foreign-country import-tariff and export-subsidy reaction functions, $\tau_{y}^{* R}\left(\tau_{y}\right)$

\footnotetext{
${ }^{25}$ The given $M\left(\hat{p}_{X}\right)$ units of imports also trade at a higher local price; however, the associated gain to total revenue is exactly offset by the corresponding loss to consumer surplus.
} 
and $\tau_{x}^{* R}\left(\tau_{x}\right)$, can be expressed analogously. The second-order conditions are satisfied provided that the political-economy weights, $\gamma_{\mathrm{m}}$ and $\gamma_{\mathrm{e}}$, are not too large. ${ }^{26}$ To this end, we assume henceforth that $\gamma_{m} \in[1,3]$ and $\gamma_{e} \in[1,3]$. This assumption ensures that the second-order conditions are satisfied; observe also that the trade policy reaction curves are upward sloping.

We next determine the import tariffs and export subsidies at which the reaction curves intersect. Given the symmetry across countries and products, such a Nash equilibrium will be described by a Nash import tariff, $\tau_{m}^{N} \equiv \tau_{x}^{N}=\tau_{y}^{* N}$, and a Nash export subsidy, $\tau_{e}^{N} \equiv \tau_{y}^{N}=\tau_{x}^{* N}$. Solving, we find that the import-tariff and export-subsidy reaction curves agree if and only if

$$
\tau_{m}^{N}=\frac{104 \gamma_{m}+51 \gamma_{e}-24 \gamma_{m} \gamma_{e}-113}{6\left[101-8 \gamma_{m}-9 \gamma_{e}\right]} ; \quad \tau_{e}^{N}=\frac{123 \gamma_{e}+56 \gamma_{m}-24 \gamma_{m} \gamma_{e}-179}{6\left[101-8 \gamma_{m}-9 \gamma_{e}\right]}
$$

Applying the conditions for prohibitive trade taxes recorded above, a positive trade volume occurs at the Nash tariffs if and only if $1 / 6>\tau_{m}^{N} \tau_{e}^{N}$, which in turn is true if and only if

$$
5 / 8+9 \gamma_{e} / 8>\gamma_{m}
$$

Thus, provided that the political significance of the import sector is not too large relative to that of the export sector, a Nash equilibrium with positive trade volume exists. Henceforth, we assume that (13) is satisfied. Figure 2 illustrates the Nash equilibrium and the reaction curves.

It is of interest to know whether the Nash import tariff and export subsidy are positive. We begin with the Nash import tariff. It is a simple matter to confirm that this tariff is positive over the relevant range of parameters, since it is in fact positive over an even larger set:

$$
\tau_{m}^{N}>0 \quad \text { for all } \gamma_{m} \in[1,3], \quad \gamma_{e} \epsilon[1,3] \text {. }
$$

Without political-economy effects, (i.e., when $\gamma_{\mathrm{m}}=\gamma_{\mathrm{e}}=1$ ), a government finds a slight import tariff desirable, since the first-order terms-of-trade benefit outweighs the second-order efficiency cost of a reduction in import volume. An additional and reinforcing effect arises when political economy is present, as the political-economy effect associated with the redistribution of surplus

\footnotetext{
${ }^{26}$ For example, if $\gamma_{m}$ gets too large, the domestic government's best choice is an infinite import tariff.
} 
to import-competing firms advances the case for an import tariff further.

The situation is more ambiguous with respect to the Nash export subsidy. We find that

$$
\tau_{e}^{N}>0 \quad \text { iff } \quad \gamma_{m}>\left[1253-861 \gamma_{e}\right] /\left[56\left(7-3 \gamma_{e}\right)\right]
$$

To interpret this condition, consider the case in which the political-economy effect is absent. In this case, the condition in (15) is violated, and the standard prescription of an export tax emerges: a slight export tariff offers a first-order benefit that is associated with the terms-of-trade effect, while the efficiency cost of reduced trade volume is second order for a small export tariff. When political-economy effects are included, however, the attractiveness of an export tariff is reduced, since an additional political-economy cost is experienced, as surplus is redistributed from domestic exporters to domestic consumers and tariff revenue. When political-economy influences are sufficiently pronounced, a slight export tariff is no longer desirable. In fact, the Nash equilibrium then entails an export subsidy. ${ }^{27}$

These conclusions are illustrated in Figure 3. The upward-sloping line corresponds to (13) and represents parameter combinations above which the Nash equilibrium net tariff exceeds the critical value of $1 / 6$; for this range of parameters, a Nash equilibrium with positive trade volume does not exist. The export-subsidy inequality given in (15) is represented by the downwardsloping line. The Nash export subsidy is positive if the political-economy weights, $\gamma_{m}$ and $\gamma_{e}$, are sufficiently large. The Nash import tariff is positive throughout the parameter space.

Finally, we return to Figure 2 and investigate the possibility of autarky Nash equilibria. The dotted line represents a "no-trade" line, along which the net tariff achieves the critical value of 1/6. It is now easy to argue that all tariff/subsidy combinations to the northwest of the point $\mathrm{AB}$ represent autarky equilibria. ${ }^{28}$ To see this, suppose that the trade policy choices in good $\mathrm{x}$

\footnotetext{
${ }^{27}$ Grossman and Helpman (1995a) also note that an export subsidy is possible in a Nash equilibrium when the export sector has significant political power.

28 The critical trade policy values associated with the point $\mathrm{AB}$ are easily calculated. Letting $\tau_{m}^{A}$ and $\tau_{e}^{A}$ denote the critical import tariff and export subsidy associated with the point $\mathrm{AB}$, we find that the set of Nash equilibria with autarky are defined by import tariffs that equal or exceed $\tau_{m}^{A}$ and export subsidies that equal or are less in value than $\tau_{e}^{A}$, where $\tau_{m}^{A}=(1 / 4)\left[\gamma_{e}-(1 / 3)\right] ; \tau_{e}^{A}=(1 / 18)\left[4 \gamma_{m}-7\right]$.
} 
place the countries in this region, and consider the options available to the domestic government. Holding fixed the foreign-country export policy, if the domestic country is to deviate and induce a positive volume of trade, then it must cut its import tariff substantially and thereby create a net tariff that lies below the dotted no-trade line. But such an outcome is worse for the domestic government than is point $\mathrm{A}$, which itself gives the autarky outcome. ${ }^{29}$ Thus, the domestic government cannot benefit by deviating, and so the autarky trade policy is an equilibrium policy.

We summarize the results of this subsection with the following:

Proposition 6: In the static tariff game,

(i). there exists a unique Nash equilibrium with positive trade volume, and this equilibrium is described by (12).

(ii). in the Nash equilibrium with positive trade volume, the Nash import tariff is positive, but the Nash export subsidy is positive if and only if the political-economy parameters are sufficiently large in magnitude, as formalized in inequality (15).

(iii). there also exist a continuum of autarky Nash equilibria, and the set of such equilibria can be characterized in terms of a critical import tariff and export subsidy level.

\section{III.3 Reciprocal Trade Agreements}

In this subsection, we characterize the reciprocal trade agreement that is efficient from the governments' perspective. We then define politically optimal tariff policies for our partialequilibrium model and compare the efficiency properties of Nash and politically optimal tariffs. Finally, we exploit the specific structure of our model in order to gain more insight into the role of the political-economy parameters in the determination of the various tariff policies.

An efficient trade agreement will implement trade policies that maximize joint welfare $\mathrm{W}+\mathrm{W}^{*}$. A first observation is that joint welfare is a function only of the net tariff levels. To see this, notice from the definitions of $\mathrm{W}$ and $\mathrm{W}^{*}$ that their sum is independent of world prices (since market clearing requires that $M\left(\hat{p}_{x}\right)=E^{*}\left(\hat{p}_{x}^{*}\right)$ and $E\left(\hat{p}_{y}\right)=M^{*}\left(\hat{p}_{y}^{*}\right)$ ). Intuitively, a change in world prices holding local prices fixed simply redistributes income across countries, and in our partial-equilibrium setting such a redistribution does not affect joint welfare, since the marginal

\footnotetext{
${ }^{29} \mathrm{As}$ in the proof of Proposition 2 in the previous section, it can be shown that welfare for a country declines along its reaction curve as the policy of its trading partner becomes more restrictive.
} 
utility of income for each country is fixed at unity. It follows that only local prices matter for efficiency. But, as we have seen, local prices depend only on the net trade impediments in each sector, and so joint welfare is entirely determined by net tariffs.

Given the symmetry between sectors $\mathrm{x}$ and $\mathrm{y}$, the efficient net tariff for market $\mathrm{x}$ will be the same as that for market $y$. Consequently, we may define $\mathfrak{l} \equiv \tau_{x}-\tau_{x}^{*} \equiv \tau_{y}^{*}-\tau_{y}$ and characterize the efficient level of the net trade impediment, 1 . Letting $J(\imath) \equiv W+W^{*}$ denote joint welfare, and noting that the second-order conditions, $J^{\prime \prime}(1)<0$, hold globally under our parameter restrictions, the first-order condition that $J^{\prime}(\imath)=0$ defines the efficient reciprocal trade agreement $\mathfrak{i}^{E}$ and can be written as

$$
W_{\hat{p}_{x}}+W_{\hat{p}_{x}^{*}}^{*} / \lambda_{x}^{*}=0
$$

Condition (16) may be contrasted with those in (10) that describe the Nash equilibrium policies; in particular, the terms-of-trade are relevant to government choices in (16) but not in (10). It is thus immediate from a comparison of (10) and (16) that the efficient reciprocal trade agreement will be attained if the terms-of-trade motivations from each government's Nash trade policy choices are eliminated: This corresponds to politically optimal trade policy as defined in the previous section, and such trade policy choices satisfy

$$
W_{\hat{p}_{x}}=0 ; W_{\hat{p}_{y}}=0 ; W_{\hat{p}_{y}^{*}}^{*}=0 ; W_{\hat{p}_{x}^{*}}^{*}=0 .
$$

We now exploit the specific structure of our model and derive explicit expressions for the politically optimal trade policies, and the efficient net and Nash net trade impediments. With regard to politically optimal trade policies, we impose symmetry and solve (17) for an import tariff and export subsidy, $\tau_{m}^{P O}$ and $\tau_{e}^{P O}$, that generate the local prices for each good that each government would prefer once terms-of-trade motivations have been eliminated. We find that 


$$
\tau_{m}^{P O}=\frac{4\left(\gamma_{m}-1\right)\left(3-\gamma_{e}\right)}{59-8 \gamma_{m}-9 \gamma_{e}} \geq 0 ; \quad \tau_{e}^{P O}=\frac{4\left(\gamma_{e}-1\right)\left(4-\gamma_{m}\right)}{59-8 \gamma_{m}-9 \gamma_{e}} \geq 0 .
$$

Observe that the politically optimal trade policy calls for free trade when political-economy influences are absent. Otherwise, the politically optimal trade policy involves an import tariff and an export subsidy. Consider next the efficient net trade policy which solves (16). This is given by $\imath^{E}=4\left[2 \gamma_{m}-3 \gamma_{e}+1\right] /\left[59-8 \gamma_{m}-9 \gamma_{e}\right]$. Finally, using (12), the Nash net tariff, $\imath^{N} \equiv \tau_{m}^{N}-\tau_{e}^{N}$, can be written as $\imath^{N}=\left[8 \gamma_{m}-12 \gamma_{e}+11\right] /\left[101-8 \gamma_{m}-9 \gamma_{e}\right]$. As expected, when political-economy effects are absent, the efficient net tariff corresponds to free trade and the Nash net tariff is positive.

The net tariffs may be further compared as follows. Defining the politically optimal net tariff as $\imath^{P O} \equiv \tau_{m}^{P O}-\tau_{e}^{P O}$, we have that the politically optimal net tariff is indeed efficient, as it follows easily that $\imath^{P O}=\imath^{E}$. Next, using (13), we observe that:

$$
\imath^{N_{-}} E=\frac{49\left[5-8 \gamma_{m}+9 \gamma_{e}\right]}{\left[101-8 \gamma_{m}-9 \gamma_{e}\right]\left[59-8 \gamma_{m}-9 \gamma_{e}\right]}>0
$$

Thus, whether or not political-economy effects are present, the Nash equilibrium is inefficient and results in too little trade.

We now summarize the central findings of this subsection:

Proposition 7: In the static tariff game,

(i). the politically optimal import tariff and export subsidy are non-negative.

(ii). the politically optimal trade policy is efficient.

(iii). the Nash trade policy is not efficient, as the net Nash tariff is too high and the Nash trading volume is too low.

From parts (ii) and (iii) of Proposition 7, we thus conclude that a basis for efficiency-enhancing reciprocal trade agreements arises if and only if governments are motivated at least in part by terms-of-trade effects.

Finally, it is interesting to note that $d\left(\mathfrak{\imath}^{N_{-}} \mathbf{\imath}^{E}\right) / d \gamma_{m}<0$ and $d\left(\mathfrak{\imath}^{N_{-}} \mathbf{l}^{E}\right) / d \gamma_{e}>0$. Hence, 
while trade liberalization under an efficient trade agreement simply eliminates the terms-of-trade driven restrictions that arise in the absence of such an agreement, the magnitude of this liberalization is smaller (greater) as the political weight placed by governments on import interests (export interests) is larger. This reflects the fact that a larger political weight on import interests (export interests) results in lower (higher) trade volume in the Nash equilibrium, and hence a diminished (expanded) role for terms-of-trade considerations in the Nash equilibrium trade policy choices.

\section{III.4 Reciprocity}

We conclude this section with an examination of the liberalization paths that governments might follow in moving from the Nash equilibrium to an efficient trade agreement. Given the symmetry of the model, it is natural to consider the class of symmetric liberalization paths along which $\tau_{x}=\tau_{y}^{*} \equiv \tau_{m}$ and $\tau_{y}=\tau_{x}^{*} \equiv \tau_{e}$. An important point is that any liberalization path within this class delivers the balance of concessions demanded under the principle of reciprocity. To see this, note that import volume and the terms of trade may be written, respectively, as $M_{x}(\imath) \equiv(1-6 \imath) / 7 \equiv M_{y}^{*}(\imath)$ and $p_{x}^{W}(\imath) / p_{y}^{W}(\imath) \equiv 1$. Thus, as liberalization occurs and the net tariff $\imath$ is reduced, terms-of-trade movements are neutralized and import and export volumes increase in equal amounts.

The liberalization process can be further understood with reference to Figure 4. There, we depict Nash trade policies $\left(\tau_{m}^{N}, \tau_{e}^{N}\right)$ by the point labeled $\mathrm{N}$ and politically optimal policies $\left(\tau_{m}^{P O}, \tau_{e}^{P O}\right)$ by the point labeled PO under the assumption that export interests are sufficiently powerful to secure an export subsidy in the Nash equilibrium. ${ }^{30}$ Figure 4 also depicts isoefficiency loci through both the Nash and politically optimal points. Each iso-efficiency locus gives combinations of $\tau_{m}$ and $\tau_{e}$ that hold $\mathfrak{l}$, and thus joint welfare $J\left(\imath \equiv \tau_{m}-\tau_{e}\right)$, constant. Hence, the iso-efficiency loci are linear with slope one. We label the iso-efficiency line through PO (N) by $\imath^{E} \imath^{E}\left(\imath^{N} \mathfrak{\imath}^{N}\right)$.

\footnotetext{
${ }^{30}$ It can be shown that the Nash import tariff (export subsidy) is greater (less) than the politically optimal import tariff (export subsidy). This relationship is illustrated in Figure 4.
} 
Starting from the Nash equilibrium, an efficient symmetric reciprocal trade agreement will call for the symmetric liberalization of net trade impediments (a reduction in $\imath$ ) in order to move the world from point $\mathrm{N}$ in Figure 4 to a point (any point) on the iso-efficiency line ${ }^{{ }^{E}}{ }_{\mathfrak{l}}{ }$. It is direct from the definition of $\imath^{E}$ and the concavity of $J(\imath)$ that joint welfare increases monotonically from the Nash equilibrium as $\mathfrak{\imath}$ falls to $\mathfrak{\imath}^{E}$. This liberalization process achieves Pareto improvements by "undoing" the terms-of-trade effects that caused the initial discrepancy between the Nash and efficient policies.

Thus, consistent with Krugman's (1991) three rules of "enlightened mercantilism," we find that: (1) Governments enter into negotiations seeking more open export markets ("exports are good") because this represents a less costly way to help export interests than a unilateral increase in export subsidies (which would worsen the terms of trade); (2) Import liberalization is viewed by governments as a concession ("imports are bad") since it implies reducing import tariffs below the best-response value (and giving up associated terms-of-trade benefits); but (3) Each government benefits from a concession at home that is balanced with an "equal" (terms-of-trade neutralizing) concession abroad ("other things equal, an equal increase in imports and exports is

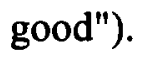

\section{Multilateral Trade Agreements in a Many-Country World}

Our next task is to extend the partial-equilibrium model of section III to a multi-country setting in order to explore several aspects of multilateral trade agreements that could not be addressed in a symmetric two-country setting. In particular, we ask how small countries are treated in an efficient multilateral trade agreement and whether there is a role for the principle of nondiscrimination -- under which each country abides by the most-favored-nation (MFN) principle and adopts a trade policy for each good that does not discriminate across trading partners -- in such agreements.

\section{IV.1 Extended Model}

We extend the model of section III in a minimal way to accommodate these questions. Home (no ${ }^{*}$ ) country demands and production functions are as before, but now the home country 
exports good $\mathrm{y}$ in exchange for imports of good $\mathrm{x}$ from $\mathrm{n}+1$ foreign $\left({ }^{*}\right)$ countries indexed by $j=1, \ldots, n+1$. The aggregate foreign demand, supply, and profit functions are as before, with foreign country 1 accounting for half of each of these aggregate magnitudes. Foreign countries 2 through $n+1$ are each identical and together account for the remaining half.

For simplicity, we assume that each of the $n+1$ foreign countries can trade only with the home country. Our assumptions on demands and production functions ensure that there will be no basis for trade among foreign countries as long as trade policies are set on an MFN basis. However, discriminatory trade policies could in principle create trade among foreign countries. We assume that exogenous trade impediments among foreign countries prevent this.

\section{IV.2 Nash Equilibria}

We characterize Nash equilibria for foreign and domestic trade policies on good $\mathrm{x}$ only. We will focus on symmetric interior Nash equilibria in which all identical foreign countries choose common (non-prohibitive) trade policies and face a common (non-prohibitive) trade policy from the domestic country. When $n=1$, the two foreign countries will be identical. When $n>1$, foreign countries 2 through $n+1$ will be identical, but they will each be small in relation to foreign country 1 . In this case the symmetric interior Nash equilibrium will have foreign countries 2 through $\mathrm{n}+1$ each choose a common export policy on good $\mathrm{x}, \tau_{\mathrm{x} 2}^{*}$, and face a common domestic-country import policy on good $x, \tau_{x 2}$. Foreign country 1 will choose an export policy $\tau_{x 1}^{*}$ and face a domestic-country import policy on good $x, \tau_{x 1}$. For all values of $\mathrm{n}$, we assume that the symmetric interior Nash equilibrium exists and is unique, an assumption which will be met if political-economy weights are not too large and, in analogy with (13), if the political significance of the import sector is not too large relative to that of the export sector.

Letting $\hat{p}_{x 2}^{*}, Q_{x 2}^{*}$ and $E_{x 2}^{*}$ denote, respectively, the common local price, production, and export volume of $\mathrm{x}$ in foreign countries 2 though $\mathrm{n}+1$, and with $\hat{p}_{x 1}^{*}, Q_{x 1}^{*}$, and $E_{x 1}^{*}$ denoting the corresponding magnitudes for foreign country 1 , we first note that $Q_{x 1}^{*}\left(\hat{p}_{x 1}^{*}\right)=\hat{p}_{x 1}^{*} / 2$, $Q_{x 2}^{*}\left(\hat{p}_{x 2}^{*}\right)=\hat{p}_{x 2}^{*} / 2 n, E_{x 1}^{*}\left(\hat{p}_{x 1}^{*}\right)=\hat{p}_{x 1}^{*}-1 / 2$ and $E_{x 2}^{*}\left(\hat{p}_{x 2}^{*}\right)=\left[\hat{p}_{x 2}^{*}-1 / 2\right] / n$, with $\hat{p}_{x 1}^{*}$ and $\hat{p}_{x 2}^{*}$ given by: 


$$
\hat{p}_{x 1}^{*}=\left[4+5\left(\tau_{x 1}^{*}-\tau_{x 1}\right)+2\left(\tau_{x 2}-\tau_{x 2}^{*}\right)\right] / 7 ; \quad \hat{p}_{x 2}^{*}=\left[4+5\left(\tau_{x 2}^{*}-\tau_{x 2}\right)+2\left(\tau_{x 1}-\tau_{x 1}^{*}\right)\right) / 7
$$

As (18) indicates, when the net tariff applied to the large (small) foreign country increases, domestic demand is diverted to the export of the small (large) foreign country, and so the local price increases in the small (large) foreign country.

We first ask under what conditions the symmetric interior Nash equilibrium will have the home country set MFN tariffs on good $\mathrm{x}$. Representing the equilibrium trade policies on good $\mathrm{x}$ as $\left(\tau_{x 1}^{N}, \tau_{x 2}^{N}, \tau_{x 1}^{* N}, \tau_{x 2}^{* N}\right)$, we provide our answer in the next proposition:

Proposition 8: $\tau_{x 1}^{N}=\tau_{x 2}^{N}$ iff $\mathrm{n}=1$

Proof: The unique symmetric interior Nash equilibrium trade policies on good $\mathrm{x}$ are given by the solution to:

$$
\begin{aligned}
& \text { I) }\left\{Q_{x}\left(\hat{p}_{x}\right)\left[\gamma_{m}-1\right]+\left[\tau_{x 2}^{N}\left(n \partial E_{x 2}^{*} \partial \partial \hat{p}_{x 2}^{*}\right)-5 \tau_{x I}^{N}\left(\partial E_{x 1}^{*}\left(\partial \hat{p}_{x 1}^{*}\right) / 2\right]\right\}+\left[5 E_{x 1}^{*}\left(\hat{p}_{x 1}^{*}\right) / 2-n E_{x 2}^{*}\left(\hat{p}_{x 2}^{*}\right)\right]=0\right. \\
& \text { II) }\left\{Q_{x}\left(\hat{p}_{x}\right)\left[\gamma_{m}-1\right]+\left[\tau_{x l}^{N}\left(\partial E_{x 1}^{*} / \partial \hat{p}_{x 2}^{*}\right)-5 \tau_{x 2}^{N}\left(n \partial E_{x 2}^{*} / \partial \hat{p}_{x 2}^{*}\right) / 2\right]\right\}+\left[5 n E_{x 2}^{*}\left(\hat{p}_{x 2}^{*}\right) / 2-E_{x 1}^{*}\left(\hat{p}_{x 1}^{*}\right)\right]=0 \\
& \text { III) }\left\{Q_{x 1}^{*}\left(\hat{p}_{x 1}^{*}\right)\left[\gamma_{e}-1\right]-\tau_{x l}^{* N}\left(\partial E_{x l}^{*} / \partial \hat{p}_{x 1}^{*}\right)\right\}+\left[-2 E_{x 1}^{*}\left(\hat{p}_{x 1}^{*}\right) / 5\right]=0 \\
& \text { IV }\left\{Q_{x 2}^{*}\left(\hat{p}_{x 2}^{*}\right)\left[\gamma_{e}-1\right]-\tau_{x 2}^{* N}\left(\partial E_{x 2}^{*} / \partial \hat{p}_{x 2}^{*}\right)\right\}+\left[-2 E_{x 2}^{*}\left(\hat{p}_{x 2}^{*}\right) /(7 n-2)\right]=0
\end{aligned}
$$

Conditions I) and II) define the domestic government's best-response tariffs on imports from foreign country 1 and foreign countries 2 through $n+1$, respectively. These conditions extend (11a) to an environment in which the domestic country imports $x$ from many sources. ${ }^{31}$ Conditions III) and IV) are exact analogues of (11b), since by construction foreign exporters can

${ }^{31}$ These conditions admit an analogous interpretation to that given for 11a) once the trade-diverting effects of discriminatory tariff changes are accounted for. For example, with regard to condition I), a slight increase in the tariff on imports from foreign country 1 will still induce an efficiency cost due to lower imports of $x$ from foreign country $1\left(-5 \tau_{x 1}^{N}\left(\partial E_{x 1}^{*} / \partial \hat{p}_{x 1}^{*}\right) / 2\right)$, but the reduction in import volume is softened somewhat by the trade diversion from foreign countries 2 through $n+1\left(\tau_{x 2}^{N}\left(n \partial E_{x 2}^{*} / \partial \hat{p}_{x 2}^{*}\right)\right)$. 
only export to one source (the domestic country). Now, if $n=1$, the symmetric interior Nash equilibrium will by definition have $\tau_{x 1}^{N}=\tau_{x 2}^{N}$, since the two foreign countries are symmetric. Thus $\mathrm{n}=1$ implies $\tau_{x 1}^{N}=\tau_{x 2}^{N}$. If $\tau_{x 1}^{N}=\tau_{x 2}^{N}$, then conditions I) and II) imply (i) $\hat{p}_{x 1}^{*}=\hat{p}_{x 2}^{*}$ which by (18) implies (ii) $\tau_{x 1}^{* N}=\tau_{x 2}^{* N}$. But together with (i) and (ii), conditions III) and IV) then imply $\mathbf{n}=1$. QED

While any given local price consistent with positive trade flows can be achieved with an MFN tariff, deviations from MFN may be required to minimize the cost to the domestic country of achieving this local price. This cost-minimization comes about by maximizing the degree of cost shifting on to one's trading partners through terms-of-trade movements. When $\mathrm{n}>1$, all foreign countries are not identical, and the maximum degree of cost-shifting for any local price desired by the domestic government will entail discriminatory tariffs. We conclude that, in the symmetric interior Nash equilibrium, deviations from MFN trade policies cannot be explained by political preference for particular local prices, but arise instead for the sole purpose of maximizing beggar-thy-neighbor terms-of-trade effects.

\section{IV.3 Multilateral Trade Agreements}

To characterize the efficient multilateral trade agreement, we choose trade policies to maximize joint government welfare. Continuing to focus only on good $\mathrm{x}$, we denote trade policies implemented by an efficient trade agreement by $\left(\tau_{x 1}^{E}, \tau_{x 2}^{E}, \tau_{x 1}^{* E}, \tau_{x 2}^{* E}\right)$. As in our earlier discussion, a trade agreement will be efficient if it succeeds in eliminating the terms-of-trade motivations from each government's Nash trade policy decisions, thereby implementing politically optimal trade policies.

We now can state:

Proposition 9: The politically optimal set of efficient trade policies satisfies the most-favorednation principle.

Proof: The politically optimal trade policies satisfy: 


$$
\begin{aligned}
& \text { I) }\left\{Q_{x}\left(\hat{p}_{x}\right)\left[\gamma_{m}-1\right]+\left[\tau_{x 2}^{E}\left(n \partial E_{x 2}^{*} \partial \partial \hat{p}_{x 2}^{*}\right)-5 \tau_{x 1}^{E}\left(\partial E_{x l}^{*} / \partial \hat{p}_{x 1}^{*}\right) / 2\right]\right\}=0 \\
& \text { II' }\left\{Q_{x}\left(\hat{p}_{x}\right)\left[\gamma_{m}-1\right]+\left[\tau_{x l}^{E}\left(\partial E_{x l}^{*} / \partial \hat{p}_{x 2}^{*}\right)-5 \tau_{x 2}^{E}\left(n \partial E_{x 2}^{*} / \partial \hat{p}_{x 2}^{*}\right) / 2\right]\right\}=0 \\
& \text { III }\}\left\{Q_{x l}^{*}\left(\hat{p}_{x 1}^{*}\right)\left[\gamma_{e}-1\right]-\tau_{x 1}^{* E}\left(\partial E_{x l}^{*} / \partial \hat{p}_{x 1}^{*}\right)\right\}=0 \\
& \text { IV' }\left\{Q_{x 2}^{*}\left(\hat{p}_{x 2}^{*}\right)\left[\gamma_{e}-1\right]-\tau_{x 2}^{* E}\left(\partial E_{x 2}^{*} / \partial \hat{p}_{x 2}^{*}\right)\right\}=0
\end{aligned}
$$

The proof now follows immediately, since $\left.\mathrm{I}^{\prime}\right)$ and II') imply $\tau_{x}^{1 E}=\tau_{x}^{2 E}(\mathrm{MFN})$.

Finally, we consider the treatment of small countries in an efficient trade agreement:

Proposition 10: Under the politically optimal efficient trade agreement, small countries are extended MFN treatment by large countries but set their own trade policies unilaterally.

Proof: To explore how small countries are treated in the politically optimal efficient trade agreement, we let $\mathbf{n}$ go to infinity. In the limit, all foreign countries but foreign country 1 will then be "small" in the sense that they are unable to affect world prices. Condition IV), which then defines the best-response export policy for each small foreign country, becomes $\left\{\hat{D}_{x 2}^{*}\left[\gamma_{e}-1\right] / 2-\tau_{x 2}^{*}\right\}=0$. But, recalling the expressions for $Q_{x 2}^{*}$ and $E_{x 2}^{*}$, this best-response function is identical to that in IV'), which defines politically optimal export policies for these countries. Hence, small foreign countries remain on their Nash reaction curves under the politically optimal efficient agreement. Finally, it is easily checked that I') and II') are independent of $\mathrm{n}$, so that by Proposition 9, the small foreign countries are still extended MFN treatment under the agreement.

QED

Thus, as a condition of entry into a politically optimal efficient trade agreement, small countries are not asked to offer reciprocal tariff reductions or bindings of any kind. This simply reflects the fact that, unlike their large trading partners, small countries are already facing the true 
costs of their trade policy choices. ${ }^{32}$ Viewed slightly differently, efficiency requires that a large country seek reciprocity in trade negotiations only from its large trading partners (those that can affect world prices) and that it extend its negotiated concessions unilaterally on an MFN basis to all other countries. This is essentially what is accomplished by the principle of MFN in combination with the GATT practice of negotiations among "principle suppliers. ${ }^{" 33}$

Finally, we comment on the two main exceptions to the MFN principle allowed in GATT, namely, the Generalized System of Preferences (GSP) and the allowance for the creation of free trade areas and customs unions (Article XXIV). Under GSP, developing countries are given special and differential access to the markets of developed countries as a result of distributional concerns. It is straightforward to show in the model of this section that, under an efficient trade agreement, if the home country wishes to transfer income to foreign countries 2 through $n+1$ but not to foreign country 1 , then a violation of MFN is required, and with it such a transfer can be accomplished without efficiency costs i.e., holding all local prices at their politically optimal levels. This distributionally-motivated violation of MFN can be thought of as corresponding to GSP, and hence GSP can indeed be interpreted within our framework. As for MFN exceptions for the purpose of the formation of free trade areas and customs unions, we note that the politically optimal efficient trade agreement will allow for the formation of free trade areas or customs unions only if countries would choose to form them when external terms of trade are held fixed. ${ }^{34}$ If together the joining countries are large, then any diversion of trade from outside the free trade area or customs union to within will raise the external terms of trade for member countries, and thereby shift a portion of the cost of their decision to join on to outside countries. This suggests that an efficient multilateral trade agreement might allow exceptions to MFN for

\footnotetext{
${ }^{32}$ Of course, this does not necessarily imply that small countries should be allowed to "free ride" on the agreement, as they might be asked to reciprocate in some way. But efficiency concerns dictate that reciprocity not take the form of trade policy commitments in this case.

${ }^{33} \mathrm{~A}$ further implication of Proposition 10 is that changing relative country size brings with it changing demands for reciprocity. This is suggestive of the "diminished giant syndrome" observed by Bhagwati $(1988,1991)$, whereby the relative decline within the world economy of Britain at the end of the nineteenth century and of the United States near the end of the twentieth century in each case spelled the decline of a hegemonic power and brought with it in each country an increased emphasis on reciprocity with trading partners.
}

${ }^{34}$ This notion bears some resemblance to the results of Kemp and Wan (1976), who focus on customs unions that form and make adjustments to their external tariffs in such a way as to hold the external terms of trade fixed. 
the purpose of forming free trade areas and customs unions in only those cases where trade diversion from outside countries into the free trade area or customs union is small. This is one interpretation of the conditions laid out in GATT's Article XXIV to which free trade areas and customs unions involving GATT-member countries must conform (Bhagwati, 1991, p.66 ).

\section{Export Subsidies}

In the preceding sections, we have argued that the terms-of-trade implications of trade policy intervention confront countries with less than the true costs of protecting their importcompeting sectors and exaggerated costs of stimulating their export sectors. This leads to a temptation for governments to oversupply policies directed toward import protection and undersupply policies directed toward export promotion relative to the efficient policy choices given their domestic objectives. The central purpose of a reciprocal trade agreement is then to confront governments with the true costs of trade intervention, which has the effect of inducing them to choose less trade-restrictive policy combinations and thereby stimulate trade.

There are many ways that countries can adjust their policies to increase trade volume. This is implicit in Figure 4, where the movement from the inefficient Nash point to a point on the efficiency locus could be engineered with a variety of trade policy changes. For example, countries may proceed in a linear fashion from the Nash trade policy to the politically-optimal trade policy depicted in Figure 4. Reciprocal trade agreements would then involve an exchange of import tariff reductions and export subsidy increases across countries.

As this possibility suggests, one implication of our analysis is that promises to increase export subsidies should figure prominently in reciprocal trade agreements, since such policy changes can increase trade volume just as effectively as reductions in import tariffs. ${ }^{35}$ As Jackson (1989) notes, however, the treatment of export subsidies in GATT and now its successor, the WTO, is perplexing and controversial. Consistent with our analysis, it is sometimes argued that

\footnotetext{
${ }^{35}$ We have not modeled here the manner in which governments enforce a reciprocal trade agreement. As we and others have argued previously (Bagwell and Staiger, 1990, Dam, 1970, and McMillan, 1986, 1989), trade agreements must be self-enforcing. They thus may be understood in terms of equilibria of an infinitely-repeated tariff game, in which a deviation from the agreement induces retaliation from trading partners in the future. In the most-cooperative equilibria of the repeated tariff game, it can be shown that countries both lower their import tariffs and raise their export subsidies, as compared to those selected in the Nash trade policy.
} 
export subsidies expand the volume of trade, enhance consumer welfare and should be encouraged. Others take a less sanguine view of export subsidies, arguing that such subsidies create "unfair" advantages and should be prohibited. These conflicting views are manifested in the ambiguous manner in which subsidies are treated in GATT and now the WTO. For example, GATT and the WTO prohibit export subsidies on most products; yet, the enforcement of this prohibition is weak, and the related policy of subsidizing R\&D is not prohibited. ${ }^{36}$

As Brander and Spencer (1985) have argued, when export sectors are imperfectly competitive in the Cournot sense, it is possible to rationalize the beneficial consequences of export subsidies with the desire of some countries to prohibit their use. In their model, each of two exporting countries is tempted to offer an export subsidy, in order to shift profits in the ensuing Cournot competition. Since both exporting governments face this temptation, a Prisoners' Dilemma problem arises between the exporting countries, as they would each do better if export subsidies were prohibited than if they were allowed to "compete" with subsidies. World welfare, however, rises when exporting countries compete in subsidies, since the gain to consumers in the importing country more than offsets the loss in welfare to the exporting countries.

In this section we reconsider the role for strategic export subsidies in the context of our competitive partial-equilibrium model. The search for strategic export subsidies in competitive markets might appear ill-conceived. Helpman and Krugman (1989, p.88) explain:

Clearly, the case where a domestic industry faces a perfectly competitive foreign industry does not lend support to the idea of subsidized export promotion. Indeed, except in the polar case of a domestic monopolist, the optimal policy is an export tax that improves the exporting country's terms of trade. The most famous insight of the strategic trade policy argument is that this may change when the foreign industry is imperfectly competitive.

By contrast, we argue here that the main conclusions of the strategic trade policy argument are maintained when the export industries are perfectly competitive, provided that government

\footnotetext{
${ }^{36}$ In addition to R\&D subsidies, preferential loan rates are often extended from governments to their exporters. Rather than attempt to tightly constrain these export policies with strong proscriptions, GATT (and now the WTO) has opted to allow importing countries the right to impose countervailing import duties when export subsidies are present, and has then focussed on restraining the use of countervailing duties.
} 
objectives are influenced by both terms of trade and political-economy considerations. ${ }^{37}$

To develop this argument, we follow Brander and Spencer (1985) and assume that Countries A and B are identical and export a homogeneous good to Country $\mathrm{C}$, where all consumers reside. Countries A and B are allowed to each select specific export subsidies, and for simplicity it is assumed that Country $\mathrm{C}$ does not intervene in trade. We depart from Brander and Spencer with the assumption that the export industries in Countries A and B are perfectly competitive. Following the framework developed above, we assume that the export industry for Country $A$ has supply and profit functions, $Q\left(P_{A}\right)=P_{A} / 2$ and $\Pi\left(P_{A}\right)=\left(P_{A}\right)^{2} / 4$, where $P_{A}$ denotes the price of the export in Country A. Similarly, the export sector for Country B is described by a supply function, $Q\left(P_{B}\right)=P_{B} / 2$, and a profit function, $\Pi\left(P_{B}\right)=\left(P_{B}\right)^{2} / 4$, where $P_{B}$ denotes the price of the export in Country $\mathrm{B}$. The demand function in Country $\mathrm{C}$ is given by $\mathrm{D}\left(\mathrm{P}_{\mathrm{C}}\right)=1-\mathrm{P}_{\mathrm{C}}$. We develop most of our arguments using the general notation for supply, demand and profit functions; specific functional forms are used when we characterize the solutions in closed form.

Prices satisfy arbitrage conditions $\mathrm{P}_{C}=\mathrm{P}_{\mathrm{A}}-\mathrm{S}_{\mathrm{A}}$ and $\mathrm{P}_{\mathrm{C}}=\mathrm{P}_{\mathrm{B}}-\mathrm{S}_{\mathrm{B}}$ and a market-clearing condition

$$
D\left(P_{C}\right)=Q\left(P_{A}\right)+Q\left(P_{B}\right)
$$

where $\mathrm{s}_{\mathrm{A}}$ and $\mathrm{s}_{\mathrm{B}}$ are the specific export subsidies in Countries $\mathrm{A}$ and $\mathrm{B}$, respectively. These yield the market clearing price in Country $\mathrm{C}, \mathrm{P}_{\mathrm{C}}\left(\mathrm{s}_{\mathrm{A}}, \mathrm{s}_{\mathrm{B}}\right)$, which is decreasing in $\mathrm{s}_{\mathrm{A}}$ and $\mathrm{s}_{\mathrm{B}}$ provided only that $Q^{\prime}>0>D^{\prime}$. Next, we may define the market clearing prices in Countries $A$ and $B$ as $\hat{P}_{A}\left(S_{A}, P_{C}\left(S_{A}, S_{B}\right)\right) \equiv P_{C}\left(S_{A}, S_{B}\right)+S_{A}$ and $\hat{P}_{B}\left(S_{B}, P_{C}\left(S_{A}, S_{B}\right)\right) \equiv P_{C}\left(S_{A}, S_{B}\right)+S_{B}$. We have that $\hat{P}_{A}$ increases as $\mathrm{s}_{\mathrm{A}}$ rises, assuming that $\mathrm{Q}^{\prime}>0>\mathrm{D}^{\prime}$, and an analogous observation applies for $\hat{P}_{B}$. Our particular functional forms satisfy these provisions, and the market clearing price for $\mathrm{P}_{\mathrm{C}}\left(\mathrm{s}_{\mathrm{A}}, \mathrm{s}_{\mathrm{B}}\right)$ is $1 / 2-\left(\mathrm{s}_{\mathrm{A}}+\mathrm{s}_{\mathrm{B}}\right) / 4$. It can now be verified that trade is not prohibited from either exporter provided that $2>\max \left\{\mathrm{s}_{\mathrm{B}}-3 \mathrm{~s}_{\mathrm{A}}, \mathrm{s}_{\mathrm{A}}-3 \mathrm{~s}_{\mathrm{B}}\right\}$, a condition which holds in the equilibrium derived below.

\footnotetext{
${ }^{37}$ In fact, the case for a strategic trade policy in a competitive market is in some respects stronger than that for imperfectly competitive markets, since conclusions drawn from the imperfect-competition model are highly sensitive to the specific nature of the oligopoly game (Eaton and Grossman, 1986; Maggi, forthcoming) and the number of domestic firms (Dixit, 1984). See also Feenstra (1986), who in a perfectly competitive 3-good general-equilibrium model develops conditions on demand complementarities across products under which export subsidies on a single export good would improve a country's overall terms of trade and could therefore be welfare improving. Feenstra does not, however, consider the strategic issues across countries which are our focus here.
} 
Government welfare functions for the three countries are defined as follows:

$$
\begin{aligned}
& W_{A}\left(\hat{P}_{A}\left(s_{A}, P_{C}\left(s_{A}, s_{B}\right)\right), P_{C}\left(s_{A}, s_{B}\right)\right) \equiv \gamma_{e} \Pi\left(\hat{P}_{A}\right)-\left[\hat{P}_{A}-P_{C}\right] Q\left(\hat{P}_{A}\right) \\
& W_{B}\left(\hat{P}_{B}\left(s_{B}, P_{C}\left(s_{A}, s_{B}\right)\right), P_{C}\left(s_{A}, s_{B}\right)\right) \equiv \gamma_{e} \Pi\left(\hat{P}_{B}\right)-\left[\hat{P}_{B}-P_{C}\right] Q\left(\hat{P}_{B}\right) \\
& W_{C}\left(P_{C}\left(s_{A}, s_{B}\right)\right) \equiv \int_{P_{C}}^{1} D(P) d P,
\end{aligned}
$$

where as above $\gamma_{\mathrm{e}} \geq 1$ with strict inequality holding when political-economy considerations influence the government. Observe that the world price in this model is given by $\mathrm{P}_{\mathrm{C}}$, and it is direct from (19) and the definition of government welfare above that a change in $\mathrm{P}_{\mathrm{C}}$ simply reflects an income transfer, having no effect on the combined welfare of the three governments.

We consider now the optimal subsidy function for the government of Country $A$. Maximizing $W_{A}$ with respect to $s_{A}$, we find the following first-order condition:

$$
\partial W_{A} / \partial \hat{P}_{A}+\lambda \partial W_{A} / \partial P_{C}=0
$$

where $\lambda$ reflects the impact of the subsidy on the terms of trade, defined by $\lambda \equiv\left[\partial P_{C} / \partial s_{A}\right] /\left[d \hat{P}_{A} / d s_{A}\right]$, which is negative provided only that $Q^{\prime}>0>D^{\prime}$. In the model developed here, we have that $\lambda=-1 / 3{ }^{38}$ The first-order condition in (20) may be rewritten as

$$
\left\{Q\left(\hat{P}_{A}\right)\left(\gamma_{e}-1\right)-s_{A} Q^{\prime}\left(\hat{P}_{A}\right)\right\}+\lambda Q\left(\hat{P}_{A}\right)=0
$$

While the political-economy effect $\left(\ell\left(\hat{P}_{A}\right)\left(\gamma_{e}-1\right)\right.$ ) encourages the subsidization of exports, the efficiency $\left(s_{A} Q^{\prime}\left(\hat{P}_{A}\right)\right)$ and terms-of-trade $\left(\lambda Q\left(\hat{P}_{A}\right)\right)$ effects go in the opposite direction. Consistent with the traditional model, when the political-economy effect is absent $\left(\gamma_{e}=1\right)$, an export tax is optimal. A symmetric first-order condition gives the optimal policy for Country B.

Let the solution to (21) be denoted $s_{A}^{R}=S_{A}^{R}\left(s_{B}\right)$, where the "R" indicates that this is Country A's export subsidy reaction function. Using the specific assumptions of our model, we

\footnotetext{
${ }^{38}$ Given the symmetry of the model, the same parameter $\lambda$ also describes the effect of a subsidy by Country B on the world and its domestic price.
} 
may solve (21) to obtain $S_{A}^{R}\left(S_{B}\right)=\left[\left(3 \gamma_{\theta}^{-4}\right)\left(2-S_{B}\right)\right] /\left[3\left(8-3 \gamma_{\theta}\right)\right]$. To interpret this finding, let us assume that $s_{B}<2$, indicating that Country B's export subsidy is not so large as to drive $P_{C}$ to zero when Country $A$ has no subsidy, and that $\gamma_{e}<8 / 3$, ensuring that the second order condition is satisfied. Observe now that an export tax is best for the government of Country A if political-economy effects are not large (i.e., $\gamma_{e}<4 / 3$ ). The optimal export policy is an export subsidy, however, if political-economy considerations are important (i.e., $\gamma_{e} \varepsilon(4 / 3,8 / 3)$ ). Finally, at $\gamma_{\mathrm{e}}=4 / 3$, the desire to subsidize for political-economy reasons is just offset by the desire to tax for terms-of-trade reasons, resulting in an optimal policy of laissez faire. With the reaction functions in place, we may now solve for the Nash equilibrium. The symmetry between Countries A and B allows the Nash subsidy level, $\mathrm{s}^{\mathrm{N}}$, to be found by solving $\mathrm{s}^{\mathrm{N}}=S_{A}^{R}\left(S^{N}\right)$, which yields $s^{N}=\left(3 \gamma_{e}-4\right) /\left(10-3 \gamma_{e}\right)$. Thus, Countries A and B select Nash export subsidies (taxes) if the political economy parameter is large (small).

We next consider a different thought experiment, and allow that the governments of Countries A and B "cooperate" and choose $\mathrm{s}_{\mathrm{A}}$ and $\mathrm{s}_{\mathrm{B}}$ so as to maximize their combined welfare. The first-order condition with respect to $s_{A}$ for this cooperative program is

$$
\partial W_{A} / \partial \hat{P}_{A}+\lambda\left[\partial W_{A} / \partial P_{C}+\partial W_{B} / \partial \hat{P}_{B}+\partial W_{B} / \partial P_{C}\right]=0
$$

Comparing (22) with (20), it is apparent that cooperative exporting countries attempt to internalize the effects of one country's export subsidy on the welfare of the other. In particular, when County A increases its export subsidy, the domestic price in Country B drops, reducing profits in Country B. Cooperative exporters recognize this terms-of-trade externality, whereas noncooperative exporters do not. Using the particular functional forms specified for the model, and exploiting symmetry across Countries $A$ and $B$, we find that the optimal cooperative export subsidy, $s^{\mathrm{C}}$, is given by $s^{c}=\left(\gamma_{e}-2\right) /\left(4-\gamma_{e}\right)$, so that the optimal cooperative policy may involve an export subsidy, but only if the political-economy parameter is quite large (i.e., $\left.\gamma_{e} \varepsilon(2,8 / 3)\right)$. We may now compare the Nash and cooperative policies, finding that

$$
s^{N}-s^{c}=4 /\left[\left(10-3 \gamma_{e}\right)\left(4-\gamma_{e}\right)\right]>0,
$$

which indicates that exporting governments reduce subsidies when they cooperate. 
Finally, we consider the efficient subsidy policy, in which $\mathrm{s}_{\mathrm{A}}$ and $\mathrm{s}_{\mathrm{B}}$ are selected to maximize the total welfare of the governments of Countries A, B and C. Recalling that changes in the world price $P_{C}$ are simply income transfers, the first order condition for $s_{A}$ are

$$
\partial W_{A} / \partial \hat{P}_{A}+\lambda \partial W_{B} / \partial \hat{P}_{B}=0
$$

It is interesting to compare the condition for efficiency, (23), with the noncooperative condition, (20). When Country A sets its policy efficiently, it internalizes the negative externality that its subsidy has on the profits in Country B. It also recognizes the positive externality that its subsidy has for consumers in Country $\mathrm{C}$, who experience a terms-of-trade improvement. This terms-of-trade improvement exactly offsets the terms-of-trade loss experienced by Countries $\mathrm{A}$ and $\mathrm{B}$, and so Country A ignores the terms of trade altogether when setting its policy in an efficient manner. Similarly, as a comparison of (22) and (23) reveals, when Country A sets its policy in a cooperative fashion, it recognizes the negative externality between Countries $A$ and B, but it doesn't internalize the terms-of-trade improvement enjoyed by consumers in Country C.

We now calculate the efficient subsidy, $s^{\mathrm{E}}$, finding that it takes the particular form $S^{E}=\left(\gamma_{e}-1\right) /\left(3-\gamma_{e}\right) \geq 0$, so that efficiency calls for an export subsidy if and only if politicaleconomy effects exist. Direct calculations yield that the efficient subsidy exceeds the Nash subsidy and thus the cooperative subsidy:

$$
s^{E}-s^{N}=2 /\left[\left(3-\gamma_{e}\right)\left(10-3 \gamma_{e}\right)\right]>0
$$

Since the Nash export subsidy exceeds the cooperative subsidy, total welfare of the three governments is higher when exporting countries act non-cooperatively than when they cooperate.

We summarize this discussion with the following proposition:

Proposition 11: In the strategic export subsidies model,

(i). the Nash export subsidy is positive (zero) (negative) if political economy effects are large (moderate) (small),

(ii). the cooperative export subsidy also can be positive if political economy effects are strong, but it is always less than the Nash export subsidy, and

(iii). the efficient export subsidy is non-negative, and it is always higher than the Nash and cooperative export subsidies. 
We conclude that the competitive model preserves the salient features of the imperfectcompetition strategic trade model: Noncooperative exporting-country governments attempt to shift profits with export subsidies and thus experience a Prisoners' Dilemma problem, and importing-country and global government welfare are higher when exporting-country governments select export subsidies non-cooperatively than when they cooperate and reduce subsidies.

In comparing the competitive model developed here with the Brander-Spencer (1985) imperfect-competition model, we note that the ranking of non-cooperative, cooperative and efficient export subsidy levels is the same in each model, being completely determined by the terms-of-trade externalities of export subsides for foreign profits and consumer welfare. The models differ only in the mechanism through which the traditional optimal export tariff is converted into an export subsidy. Export subsidies arise in the competitive model as a consequence of political concerns, whereas the Cournot nature of firm interaction generates an export subsidy in the imperfect-competition model. With regard to the treatment of export subsidies in reciprocal trade agreements, both models suggest that exporting countries prefer a ban on export subsidies in order to stem the rivalry in subsidies that otherwise occurs. Importing countries and the world as a whole lose if exporting countries are successful in this endeavor.

We have established that the scope for strategic export policy is wider than previously thought, as it extends beyond oligopolistic markets and into competitive markets. An interesting implication is that agricultural export subsidies might be interpreted from a strategic perspective. Some support for this argument is found in connection with the dispute over wheat flour trade that arose between the United States and the European Community during the 1980's. Consistent with the view that E.C. export subsidies had a strategic component, the U.S. held that export subsidies from the E.C. displaced sales by U.S. exporters in third-country markets and lowered the world price. When the E.C. was unresponsive to U.S. complaints, the U.S. retaliated with its own aggressive export subsidization program, in order to impress upon the E.C. the mutual costs that a subsidy war would entail. Eventually, the U.S. and the E.C. did cooperate and institute tighter limits on export subsidies as part of the Uruguay Round of GATT negotiations. ${ }^{39}$

\footnotetext{
${ }^{39}$ For more on the U.S./E.C. wheat flour dispute, see the interesting case study offered by Rhodes (1993). Nivola's (1993) summary also supports the interpretation of the dispute as corresponding to a Prisoners' Dilemma problem. For example, he notes that the U.S. took the lead in the 1980 's "in calling for an international halt to the
} 


\section{Conclusion}

We provide in this paper an analytic framework for the study of reciprocal trade agreements. We use this framework to establish three main results. First, we argue that political-economy factors are important for explaining the range of trade policies observed, but that these factors can not explain why governments seek reciprocal trade agreements as an institutional form for implementing their preferred policies. Rather, whether or not governments are politically motivated, Johnson (1953-54) was right: The central purpose of a reciprocal trade agreement is to eliminate the terms-of-trade driven policies that arise in the absence of such an agreement. Second, we establish an economic interpretation of the principles of reciprocity and nondiscrimination that represent the foundation of postwar reciprocal trade agreements. Finally, we offer new insights regarding the treatment of export subsidies in reciprocal trade agreements.

While these results hold over a general class of models, it is important to mention that some caveats do apply. A first caveat concerns the manner in which government preferences are represented. In deriving our results, we have assumed that the trade policy decisions of each government can be represented by the maximization of a function of its local and world prices. ${ }^{40}$ While this assumption holds in the leading formulations of the political economy of trade policy, it need not hold in all environments. For example, if the foreign profits of domestic multinationals are an important element of the domestic government payoff, then this payoff will be a function of local prices in the foreign market as well. Further, non-pecuniary externalities that cross international borders represent an additional area where reciprocal trade agreements could conceivably play a distinct role. ${ }^{41}$

A second caveat is associated with the ability of a government to make commitments to its own production sector. In our model, government trade policy choices precede production decisions, and so government policies are necessarily taken as credible by the production sector.

ruinous contest among major producing nations to bloat their agricultural exports." (Nivola, 1993, p. 37).

\footnotetext{
${ }^{40}$ In fact, domestic government objectives are also a function of local prices in each foreign market in our manycountry model of Section IV, but only when tariffs are discriminatory.

${ }^{41}$ Deardorff (1995) provides an interesting analysis of international agreements covering pollution taxes in the presence of pollution externalities that may be local or may cross international borders.
} 
In other formulations, however, a government may face a commitment problem with its production sector. When domestic commitment problems are present, it becomes possible that a government might look to a reciprocal trade agreement as a device to commit itself to more liberal trade policies than it could sustain absent the agreement. While this possibility represents a motivation for reciprocal trade agreements that is distinct from the terms-of-trade motivation developed above, it is difficult to reconcile with the mercantalist flavor that describes actual negotiations: Governments would seek reciprocal trade agreements as a way to reduce their own levels of intervention, without regard for the policy commitments of their trading partners. Thus, while commitment issues may well be important in certain circumstances, they do not appear to provide a satisfactory foundation for understanding the broad features of reciprocal trade agreements.

Despite these caveats, our conclusions are important for researchers concerned with questions related to the performance of trade agreements -- that is, the effectiveness with which the rules that implement the trade agreement achieve their desired purpose. Our results imply that the standard Johnson optimal tariff formulation provides a valid modeling framework within which to explore these questions: Since the elimination of inefficiencies that arise from terms-oftrade driven externalities is the central purpose of such agreements, the Johnson framework captures the essential problem that trade agreements are designed to address.

Finally, in pursuing a positive theory we have taken government payoffs as given. An implication is that the efficient trade agreement from the perspective of government objectives need not involve free trade. To the extent that voters are collectively motivated by national welfare considerations, an intriguing possibility is that voters may be attracted to domestic reforms that alter the political constraints under which governments operate, or to reforms directed at international institutions themselves. The design of institutions in light of their impact on the outcome of reciprocal trade agreements is an area that we leave for future research. 


\section{References}

Bagwell, Kyle and Robert W. Staiger, "A Theory of Managed Trade," American Economic Review 80, 1990.

Baldwin, Richard, "Politically Realistic Objective Functions and Trade Policy," Economic Letters 24 (1987): 287-290.

Bhagwati, Jagdish, Protectionism. (The MIT Press, Cambridge, MA: 1988).

Bhagwati, Jagdish, The World Trading System at Risk. (Princeton University Press, Princeton, New Jersey, 1991).

Brander, James A. and Barbara Spencer, "Export Subsidies and Market Share Rivalry," Journal of International Economics 18, 1985.

Chari, V.V. and Patrick J. Kehoe, "International Coordination of Fiscal Policy in Limiting Economies," Journal of Political Economy 98, 1990.

Conybeare, John A.C., Trade Wars: The Theory and Practice of International Commercial Rivalry. (Columbia University Press, New York: 1987).

Dam, Kenneth W., The GATT: Law and International Economic Organization, Chicago: University of Chicago Press, 1970.

Deardorff, Alan V., "International Externalities in the Use of Pollution Policies," mimeo, The University of Michigan, 1995.

Dixit, Avinash, "International Trade Policy for Oligopolistic Industries," Economic Journal 94 (Supplement, 1984): 1-16.

Dixit, Avinash, "Strategic Aspects of Trade Policy," in Trewman F. Bewley, ed., Advances in Economic Theory: Fifth World Congress, New York: Cambridge University Press, 1987.

Eaton, Jonathan and Gene M. Grossman, "Optimal Trade and Industrial Policy under Oligopoly," Quarterly Journal of Economics 51 (May 1986): 383-406.

Ethier, Wilfred J., Modern International Economics (W.W. Norton and Company: New York and London), Second Edition:1988.

Feenstra, Robert C., "Trade Policy with Several Goods and 'Market Linkages'," Journal of International Economics 20 (May 1986): 249-267.

Flam, Harry and Elhanan Helpman, "Industrial Policy under Monopolistic 
Competition," Journal of International Economics 22 (1987): 79-102.

Grossman, Gene M. and Elhanan Helpman, "Protection for Sale," American Economic Review 84 (September 1994): 833-50.

Grossman, Gene M. and Elhanan Helpman, "Trade Wars and Trade Talks," Journal of Political Economy 103 (August 1995): 675-708.

Grossman, Gene M. and Elhanan Helpman, "The Politics of Free-Trade Agreements," American Economic Review 85 (September 1995): 667-690.

Helpman, Elhanan and Paul R. Krugman, Trade Policy and Market Structure. (The MIT Press, Cambridge, MA: 1989).

Hillman, Arye L. and Peter Moser, "Trade Liberalization as Politically Optimal Exchange of Market Access," in M. Canzoneri, W. Ethier, and V. Grilli (eds.) The New Transatlantic Economy. Cambridge University Press (forthcoming, 1995).

Jackson, John H., The World Trading System. (The MIT Press, Cambridge: 1989).

Johnson, Harry G., "Optimum Tariffs and Retaliation," Review of Economic Studies 21, no.2 (1953-54):142-53.

Johnson, Harry G., "An Economic Theory of Protectionism, Tariff Bargaining, and the Formation of Customs Unions," Journal of Political Economy 73 (Feb.-Dec. 1965): 256-283.

Kemp, Murray C. and Henry Wan Jr., "An Elementary Proposition Concerning the Formation of Customs Unions," Journal of International Economics 6 (1976):95-97.

Krueger, Anne O., "Free Trade is the Best Policy," in Robert Z. Lawrence and Charles L. Schultze (eds.) An American Trade Strategy: Options for the 1990s. The Brookings Institution, Washington, D.C., 1990.

Krugman, Paul R., "The Move Toward Free Trade Zones," in Policy Implications of Trade and Currency Zones, A Symposium Sponsored by The Federal Reserve Bank of Kansas City, Jackson Hole, Wyoming, August 22-24, 1991.

Lindert, Peter H., International Economics. (Irwin Publishers, Homewood, Illinois, Eighth Edition: 1986).

Maggi, Giovanni, "Strategic Trade Policies with Endogenous Mode of Competition," American Economic Review (Forthcoming).

McMillan, John, "A Game-Theoretic View of International Trade Negotiations: 
Implications for the Developing Countries," in John Whalley ed. Developing Countries and the Global Trading System: Volume 1. (MacMillan, 1989).

McMillan, John, Game Theory in International Economics. (New York: Harwood, 1986).

Nivola, Pietro, Regulating Unfair Trade. (The Brookings Institution, Washington, D.C., 1993).

Preeg, Ernest H., Traders and Diplomats: An Analysis of the Kennedy Round of Negotiations under the General Agreement on Tariffs and Trade. (The Brookings Institution, Washington, D.C., 1970).

Rhodes, Carolyn, Reciprocity, U.S. Trade Policy, and the GATT Regime. (Cornell University Press, Ithaca, New York, 1993).

Robinson, J., "Beggar-My-Neighbor Remedies for Unemployment," Chapter 2 of Essays on the Theory of Employment, 2nd Edition: Basil Blackwell, Oxford, 1947.

Rodrik, Dani, "What Does the Political Economy Literature on Trade Policy (Not) Tell us That we Ought to Know," NBER WP. No. 4870, September 1994.

Scitovszky, T., "A Reconsideration of the Theory of Tariffs," Review of Economic Studies 9, 1942. 


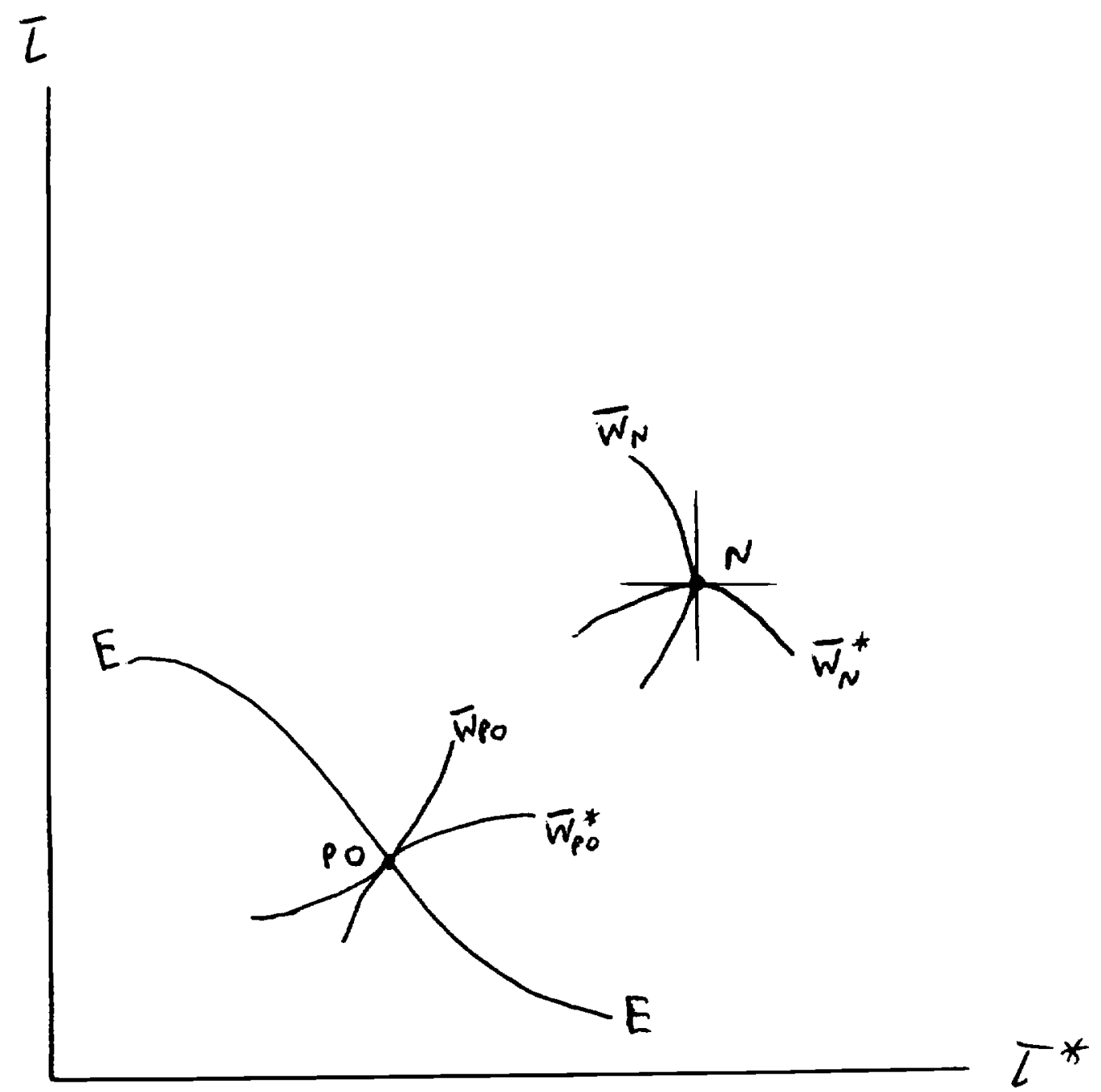

Fiqure 1 


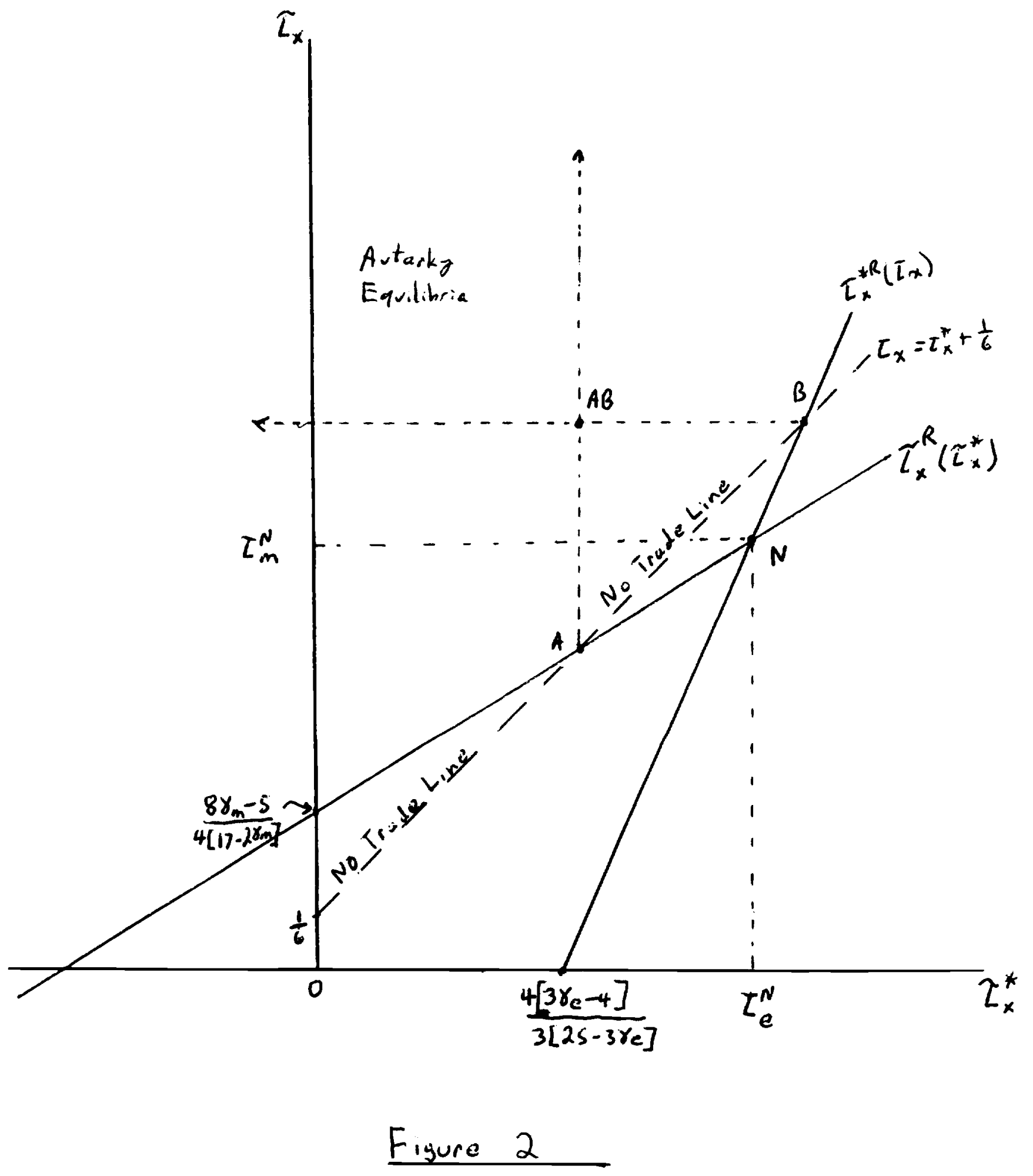




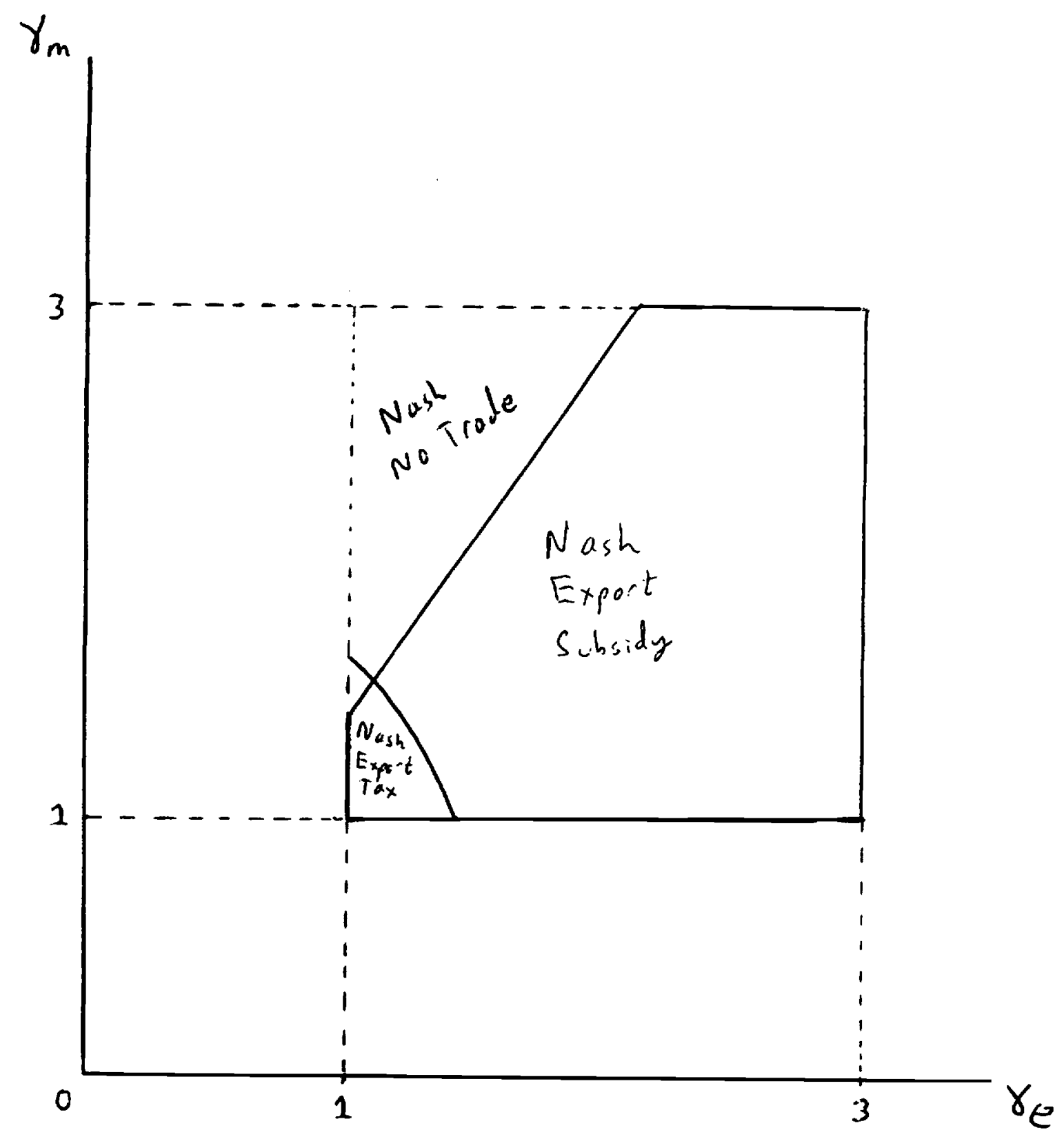

Figure 3 


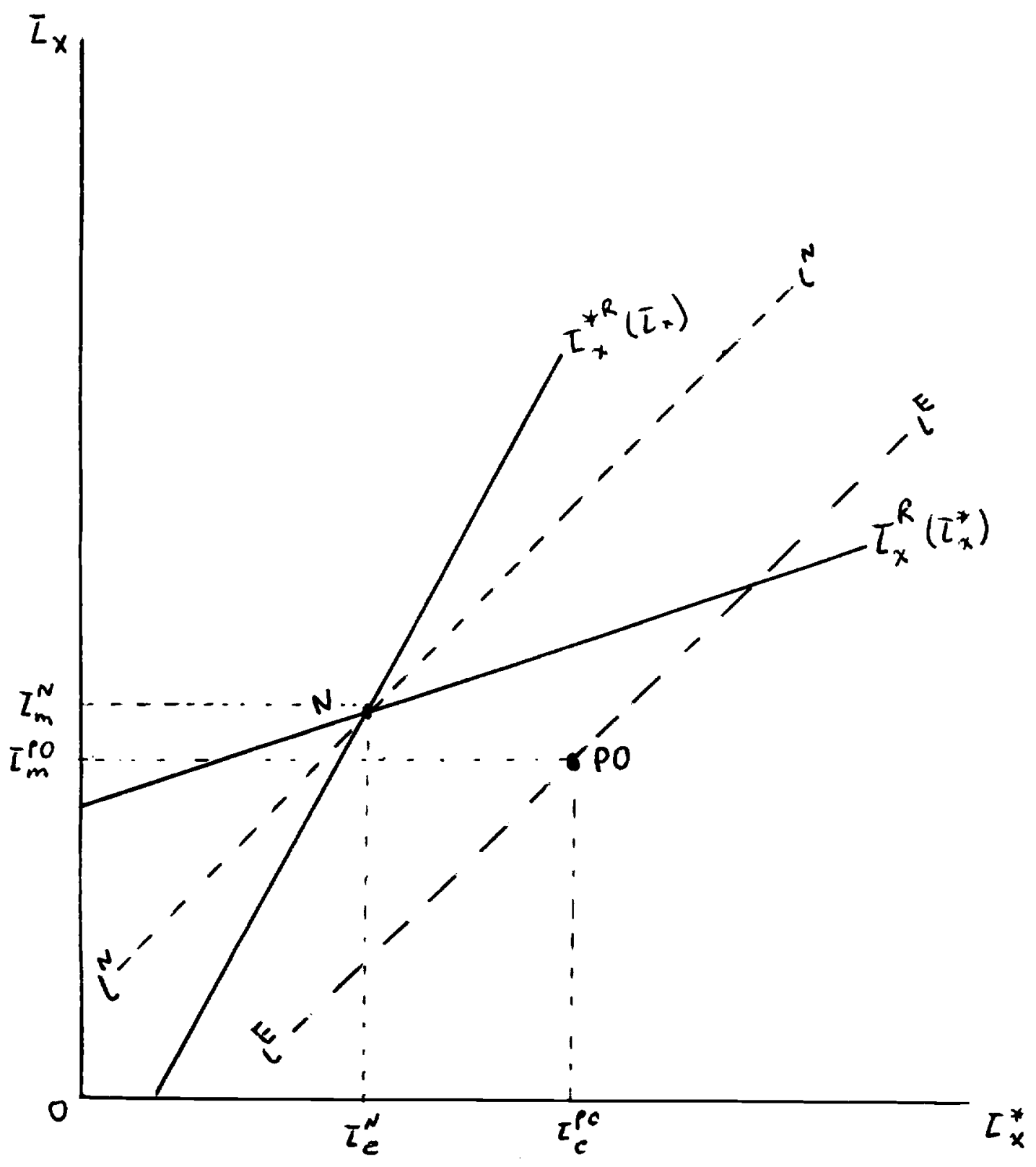

Figure 4 